IZA DP No. 8384

Diversity and Social Capital in the U.S:

A Tale of Conflict, Contact or Total Mistrust?

Willie Belton

Yameen Huq

Ruth Uwaifo Oyelere

August 2014 


\title{
Diversity and Social Capital in the U.S: A Tale of Conflict, Contact or Total Mistrust?
}

\author{
Willie Belton \\ Georgia Institute of Technology \\ Yameen Huq \\ Georgia Institute of Technology \\ Ruth Uwaifo Oyelere \\ Emory University \\ and IZA
}
Discussion Paper No. 8384
August 2014

IZA
P.O. Box 7240
53072 Bonn
Germany

Phone: +49-228-3894-0

Fax: +49-228-3894-180

E-mail: iza@iza.org

\begin{abstract}
Any opinions expressed here are those of the author(s) and not those of IZA. Research published in this series may include views on policy, but the institute itself takes no institutional policy positions. The IZA research network is committed to the IZA Guiding Principles of Research Integrity.

The Institute for the Study of Labor (IZA) in Bonn is a local and virtual international research center and a place of communication between science, politics and business. IZA is an independent nonprofit organization supported by Deutsche Post Foundation. The center is associated with the University of Bonn and offers a stimulating research environment through its international network, workshops and conferences, data service, project support, research visits and doctoral program. IZA engages in (i) original and internationally competitive research in all fields of labor economics, (ii) development of policy concepts, and (iii) dissemination of research results and concepts to the interested public.
\end{abstract}

IZA Discussion Papers often represent preliminary work and are circulated to encourage discussion. Citation of such a paper should account for its provisional character. A revised version may be available directly from the author. 
IZA Discussion Paper No. 8384

August 2014

\section{ABSTRACT}

\section{Diversity and Social Capital in the U.S: A Tale of Conflict, Contact or Total Mistrust?}

In this paper we explore the relationship between ethnic fractionalization and social capital. First, we test for time differences in the impact of ethnic fractionalization on social capital using U.S. data from 1990, 1997 and 2005. Subsequently we examine the data for evidence of the conflict, contact and hunker-down theories espoused by Putman in explaining what happens over time when individuals interact with those of differing ethnicities. We find no evidence of heterogeneity in the impact of ethnic fractionalization on social capital over time. In addition we find evidence of the conflict theory and no evidence of hunker-down or contact theories. Our results suggest that as communities become more diverse, there is a tendency for social capital to decline.

JEL Classification: D71, Z10, J10, J19

Keywords: ethnic fractionalization, social capital, trust, diversity, social networks

Corresponding author:

Ruth Uwaifo Oyelere

Emory University

Department of Economics

Rich Memorial Building

Atlanta, GA 30322-2240

USA

E-mail: ruth.oyelere@emory.edu 


\section{Introduction and Background}

Few concepts have influenced research on the development of modern society more than the growth in networks and increase in ethnic diversity. To the casual observer these two concepts appear to be moving through time on parallel courses. A more careful look reveals that the courses are anything but parallel. Instead, they are intimately related and moving through time, shaping and reshaping dynamic social, economic and political interaction across generations, nations, states, communities and organizations.

Networks form the core of modern society as technological innovation allows increased communication across vast distances. It is increasingly more likely that networks influence our choice of geographic, social, political and even economic affiliations in the form of employment. However, although networks influence outcomes, it is our core values and commonalities that lead us to develop and join networks. Ethnicity provides one of the key signals to individuals seeking networks in an uncertain world with noisy signals.

Increased immigration can impact the social, economic, and political fabrics of communities. Hence, developed nations are interested in the impact of immigrants in a broad sense. In particular, the impacts of immigrants on wages, job opportunities, student achievement and income generation in the communities where they settle have been investigated extensively. ${ }^{1}$ However, understanding the impact of increased diversity on the development of trust and social capital in communities is equally important and currently understudied. The United States is currently in the throws of a debate on how to manage the introduction of 11 million illegal immigrants into mainstream society. These numbers alone will influence the ethnic make-up of communities and ultimately impact economic, political, and social interaction across the nation.

This research seeks to examine the impact of changing ethnic diversity on the formation of networks and social capital over time. One of the principles at the core of successful networks is "trust." Individuals must trust each other if networks are to be sustained over time and be effective in accomplishing the stated goals. Trust is a dynamic concept that is developed over time through repeated interaction. Since the information provided by repeated interaction is in most cases, unavailable initially, agents rely on signals that are more broadly available, i.e., ethnicity, income levels, perceived

\footnotetext{
${ }^{1}$ See Diette and Uwaifo Oyelere (2014) on impacts of immigrants on student achievement.
} 
education level, etc.

Current research on the development of trust across communities is generally found in the economic and political science literature under the rubric of social capital. In this literature social capital is believed to be important for the development of cohesive communities, sustainable social and political organization as well as efficient and productive economic outcomes.(See Helliwell and Putnam(1995), Chhibber(1997) and Narayan and Pritchett(1997)) Though the literature appears to suggest social capital is an important concept, there is a lack of consensus on its definition and/or meaning.

In this research we avoid the definition problem by adopting the definition and measure of social capital in Rupasingha, Goetz, and Freshwater (2006), hereafter (RGF). They developed measures of social capital, which they argue are proxies for trust across communities. These measures use U.S. county level data. Following Putnam (1993), which argues that associational activities help communities to solve the collective action problem, RGF (2006) measure social capital by counting membership in sports clubs, bowling leagues, religious organizations, political clubs and the like across U.S. counties. They create an index using these data applying principal component analysis and then examine how demographic variables including ethnic fractionalization explain variation in the social capital index across counties and across time. ${ }^{2}$

Our research is related to $\mathrm{RGF}(2006)$ as their production approach provides the basic building block for the model that we use to examine how changing diversity across U.S. counties impact the production of social capital. However, our research differs from $\operatorname{RGF}(2006)$ in three ways. First, we are more interested in investigating heterogeneity in the impact of ethnic fractionalization on social capital as defined by RGF overtime. Second, we consider a wider period of time (1990-2005) than RGF. The final goal of our paper is to test, across U.S. counties, the applicability of the contact, conflict and hunker-down theories espoused by Putman (2007).

Specifically, in our research we examine two related questions.

- First, are there time differences in the association between ethnic diversity of a county and social capital?

- Second, is there evidence supporting the contact, conflict or hunkerdown theories of social interaction in the United States?

\footnotetext{
${ }^{2}$ Like most indexes, the RGF social capital measure has limitations. We discuss some of these in section 7 .
} 
Putnam (2007) argues that there are three possible outcomes of the impact of increased diversity on social connections. The first is what he has labeled the contact theory. This theory suggests that increased contact with people who are unlike one another ethnically leads to increased "interethnic tolerance". In effect, the more contact we have across ethnic lines the more likely it is that we overcome our apprehension and ignorance in order to trust each other more. The second theory, the conflict theory, suggests that contention over scarce resources, the fear of redistributive policies and other competitive activities leads to increasing out-group distrust i.e., the more ethnic groups have opportunity for close interaction across groups, the more they stick to their own group and the less they trust other groups. (Page 142 of Putnam 2007 for references). Putnam (2007) identifies a third theory that he labels the hunker-down theory. He argues that more across ethnic group interaction leads not only to more out-group distrust but also to more in-group distrust. In effect, increased across ethnic group interaction leads not only to more out-group distrust but more in-group distrust as well.

To test these theories and the heterogeneity of the impact of ethnic fractionalization, we make use of U.S. Census data for 1990, 1995 and 2005, and also the data on social capital from RGF (2006). To answer our first question, similarly to RGF (2006) we estimate a model of social capital production at the county level across three survey periods. We control for potential exogenous factors that are likely to affect social capital formation at the municipal level. Moreover, we also address potential omitted variable bias by including state and time fixed effects. We test for heterogeneity in the impact of ethnic fractionalization on social capital over time by comparing the estimated impacts, across the three periods, for statistical difference. While our inclusion of state level fixed effects and other controls in our county level empirical model reduces the potential for selection bias, we cannot completely rule out the possibility that our estimated effects could be biased. However, given our first question is focused more on investigating time differences in the impact of ethnic fractionalization rather than deriving a consistent estimate the impact of ethnic fractionalization on social capital, as long as the potential bias in our estimated coefficients are time invariant, a consistent estimate of a change in the impact can be inferred. ${ }^{3}$

To answer our second question we pool the data and focus on testing the models of social interaction suggested in Putman (2007). To test these models we first focus on the sign of our estimated ethnic fractionalization

\footnotetext{
${ }^{3}$ While we cannot think of any reason why we should have a time varying bias, we cannot rule out this possibility.
} 
coefficient. An estimated effect greater than zero (positive sign) provides evidence in support of contract theory. In contrast if our estimated impact is negative. Our results provides evidence suggestive of conflict theory. Finally, if our estimated impact of ethnic fractionalization variable and the size of the dominant group in a municipality are both negative, our results provide evidence of the hunker-down theory. As estimated effects free of bias is critical to our being able to identify which of these theories is relevant, we exploit the panel nature of our data and estimate effects using a fixed effect model specification. With our fixed effects specification, we eliminate most sources of selection bias by identify effects using only variation over time within a municipality.

Our results suggest that after controlling for potential selectivity issues, there are no significant time differences in the relationship between ethnic fractionalization and social capital between 1990-2005. While the magnitude of the coefficient seems to have increased slightly over time, the estimated effects for the three time periods are not statistically different. Hence, the effect of ethnic fractionalization appears to be stable over the period of time of our analysis. We also find no evidence in support of the contact theory and no consistent evidence for the hunker-down theory. In contrast, our estimates provides strong evidence in support of Putman's conflict theory.

This paper contributes to the literature by providing answers to questions that are not only timely, but could inform current discussions on the potential effects of increased diversity through immigration. The U.S. has experienced a significant influx of immigrants over the last few decades and this increase in immigrants has increased ethnic diversity within and across communities in the U.S. While there is evidence of the positive impact of immigrants on native wages (Ottaviano and Peri, 2012) ${ }^{4}$, less is known as to the possible impact of increased diversity on social capital formation within communities. In addition, given that the past literature suggests that social capital is an important determinant of macroeconomic performance (see Durlauf, 2002) and social capital may be influenced by increased diversity, it may be useful to understanding the relationship between social capital and diversity. Further, since Putnam (2000) suggests that social capital may be declining within communities in the U.S., it is imperative that we understand the drivers of social capital. Finally, while individuals like Putman (2007) have put forward social interaction models hypothesizing the po-

\footnotetext{
${ }^{4}$ Other past research, like Card (2005), uses data from the 2000 Census and shows no significant effect on relative wages of native dropouts from relative supply of less-educated workers.
} 
tential outcomes of increased social interaction with individuals of diverse ethnicities, empirical evidence supporting or refuting these theories has not been established. Our paper fills this gap for the U.S. by providing evidence that between 1990-2005 increases in ethnic fractionalization in communities has not fostered increased social capital formation.

The rest of our paper proceeds as follows. In section two we review the past literature on social capital, group formation and trust. Section three provides our conceptual framework and testable hypotheses. In section four, we provide a summary of the data sets we use in this paper and descriptive analysis of the data. Section five provides our empirical model and results, while section six provides robustness checks. We conclude in section seven.

\section{Literature Review}

For most economists, the notion of social capital goes back to the works of North and Thomas (1973) and Mansour Olsen (1971). These two works, in many circles, are thought to address two distinctly different questions. North and Thomas (1973) examine the role of institutions in the rise of the western world whereas Olsen (1971) investigates impetus and theory of collective actions. Both of these works, in a more general sense, address the notion of how human interaction implicate and inform down stream outcomes. In both cases the major question to be addressed is how does current and past social interaction across individuals and groups influence, or in some cases create, the economic structure that produces the best social and economic outcomes, given the scarcity of resources. Putnam (1993, 1999, and 2000) formalized these notions when he investigated the evolution of democracy in Italy and the disappearance of social capital in America. He provided formal methodology for measuring social capital in his work "The Collapse and Revival of the American Community" (2000).

Economist for the most part have argued that social capital directly and positively influences economic growth and development in that trust among economic agents makes way for more cooperation and efficient interaction in the solution of the collective action problem. (see Colman 1988, 1990 and Putnam 1993). Though most research has supported the notion that social capital does indeed enhance and in some cases lead to more efficient production, there are a number of detractors. (See Portes 1998, Arrow 2000, Solow 2000, Defilipis 2001 and Durlauf 2002). Detractor generally find that the definition of social capital is problematic and they have trouble with making reference to linkages that enhance interaction as "capital". This 
research does not discuss the definition and measurement issues of social capital but simply adopts the Putnam and Olsen definitions of social capital and uses the Putnam approach to measurement that is operationalized in RGF (2006).

Our research has its roots in the work of Alesina and La Ferrara (2004) and Putnam (2007). These papers examine the impact of ethnic diversity on social capital. Alesina and La Ferrara (2004) examines social capital indirectly as they argue that increased diversity leads communities to pursue the creation of more private goods at the expense of public goods. Implicit in their argument is the conflict theory which argues that as ethnic diversity increases ethnic groups, competition increases amongst said groups for scarce resources, thus decreasing social capital. ${ }^{5}$

Putnam (2007) argues that increased diversity, within and across countries, leads researchers to think about how the increase impacts social, economic, and political outcomes. The core of this literature suggests that networks are valuable in much the same way as physical capital and labor. Since networks are made up of people who share common values, associated norms of reciprocity and trustworthiness, then it is important to understand how networks respond when the opportunity or imperative for growth is extended across diverse groups. In effect, how does diversity impact the social capital, the adhesive that holds networks together?

\section{Conceptual Framework}

To understand and conceptualize how social capital is formed and augmented over time, we focus on Blau's (1977) theory based on the homophily principle. The homophily principle suggests that people who are similar across sociodemographic dimensions are more likely to interact than people who are dissimilar. Based on Blau's homophily principle, people of similar sociodemographic dimensions are more likely to form bonds that engender trust and hence improve social capital. RGF's definition of organizations suggests that members of organizations tend to exist in similar sociodemographic space. The theoretical space is defined across sociodemographic characteristics such as race, income levels, levels of educations, age and other demographic factors. McPherson, Popielarz, and Drobiic (1992), hereafter (MPD), use Blau's model in a dynamic context in an effort to examine the

\footnotetext{
${ }^{5}$ Our research takes a more direct approach by following the work of Putnam (2007) which, through the use of survey data, examines directly the impact of diversity on social capital.
} 
impact of social networks on organizational behavior over time. In particular, MPD's model examines how sociodemograpic changes over time in the make-up of the membership of a group impacts the missions and goals of the organization.

The interaction over time among individuals within the group is governed by the homophily principle, which implies more similar people are likely to have deeper and more frequent interactions. Homophily structures the flow of information among members of the group. Hence information flow among members of similar sociodemographic space moves through fewer filters than information flowing to members in a more distant sociodemographic space. These distances in social spaces are also proxies for distance in general, since people who are located far away generally have less in common socially.

While the aforemention conceptual framework explains the basic structure of groups, an evolutionary model is needed to explain how groups change over time as members enter and leave. MPD (1992) suggests that there are three general factors that must be considered: variation, retention, and selection. Variation in sociodemographic characteristics such as race, income, age and many other demographics are important in understanding the evolution of groups across time. Retention examines how groups recruit members in an effort to keep their sociodemographic space constant. When a group is able to keep its' sociodemographic space constant then it will exhibit more "group-like" behavior. Selection or the recruitment of new members is of concern because group members tend to bring in or select new members for the group through the homophilous network ties among members. Since it is the selection process that governs the evolution of the group over time, it is important to identify whether new entrants into the group are stabilizing or disruptive selections.

Stabilizing selection occurs when recruitment/attrition ratio is smaller at the edges of the niche. Greater rate of loss or smaller rate of gain away from the group mean characteristics makes it more specialized over time.

Disruptive selection occurs where there is more gain than loss at the edges, causing the group to generalize and increase variance over one dimension i.e. race, age or other demographic dimensions.

Selection of new members over time can clearly impact the behavior of the organization in its effort to achieve goals. The focus of this paper is the relationship between variation in a demographic variable associated with group members' and trust across the group's membership. More specifically, we examine how variations in the race and ethnicity of group mem- 
bers impact the production of social capital. Putnam (2007) and others have argued that there are three possible theories that explains the impact of changing diversity on social capital: the contact theory, the conflict theory and the hunker-down theory. The contact theory suggests that greater racial diversity among social groups will lead to greater tolerance and trust among different racial groups. In effect, greater diversity leads to more outgroup solidarity. This greater level of out-group trust leads to increased production of social capital. The conflict theory suggests that increased diversity actually encourages out-group distrust and increased in-group solidarity. Implying that increased contact with other ethnic groups engenders more distrust of people of different ethnicities and a preference for ones' own group. This distrust within communities reduces social capital formation. Thus, there is a negative correlation between diversity and social capital. The hunker-down theory suggests that not only does increased diversity reduce out-group trust but will also reduce in-group trust. In effect, increased diversity reduces social capital across all groups.

To investigate the three theories in a more formal fashion we adopt a model similar to that of (RGF) 2006. Equation (1) reveals that social capital $\mathrm{S}$, in county $\mathrm{c}$, is a function of ethnic fractionalization e and a vector of control variables $\mathrm{Z}$.

$$
S_{c}=\beta_{0}+\beta_{1} e_{c}+Z_{c}^{\prime} \beta_{3}+\epsilon_{c}
$$

\section{Detailed Data Description}

The measure of social capital used in this research is from the Northeast Regional Center for Rural Development at College of Agricultural Sciences at Penn-State developed by (RGF) (1992). This data repository contains social capital data for the years 1990, 1997, 2005 and 2009 for each county in the continental U.S. We make use of 1990, 1997 and 2005 data solely for consistency because the calculation of the index changed for the 2009 survey. ${ }^{6}$ Table (1) provides the components used by $\mathrm{RGF}(2006)$ to build the social capital index. The social capital index is a composite index created using principle components analysis. The specific variables used in the index are: aggregate total of listed organizations, non-profit organizations,

\footnotetext{
${ }^{6}$ Specifically the method using in creating the social capital index for 2009 , is incompatible with the data information available for 1990. While the 1997 and 2005 surveys can be recalculated to be compatible with the method used in the 2009 panel.
} 
the census response rate, and voting fraction. ${ }^{7}$ Summary statistics for the variables used to create the social capital index are presented in Table (2). Because the social capital can range from negative to positive, the mean values in each panel are generally near zero. ${ }^{8}$

Table 1: Components of Social Capital Index

Name Description

\begin{tabular}{lc}
\hline \hline Bowling centers & Total number of bowling centers \\
Civic associations & Total number of civic and social associations \\
Gyms & Total number of physical fitness facilities \\
Golf courses & Total number of golf courses \\
Religious organizations & Total number of religious organizations \\
Sports clubs & Total number of sports clubs \\
Recreation clubs & Total number of recreation clubs \\
Political groups & Total number of political organizations \\
Professional groups & Total number of professional organizations \\
Business groups & Total number of business organizations \\
Labor groups & Total number of labor organizations \\
Other groups & Total number of other membership organizations \\
Total organizations & Aggregate sum of organizations listed above \\
Census responses & Census response rate \\
Non-profit organizations & Total number of not-for-profit organizations \\
Population & Total residential population \\
Voting fraction & Voting fraction from nearest Presidential election \\
\hline
\end{tabular}

The definition of control variables used in our empirical analysis are found in Table (3). These data are taken or derived from CenStats Databases of the United States Census Bureau (2010). The independent variables are constrained to all counties in the continental United States. Summary statistics of these variables can be found in Table (4) and the description of how these variables are calculated is highlighted in the appendix.

\footnotetext{
${ }^{7}$ It should be noted that voting fraction is taken from the nearest Presidential election. For the 1997 and 2005 panels, these are the 2000 and 2004 Presidential elections, respectively. The 1990 panel averages 1988 and 1992 Presidential election.

${ }^{8}$ The social capital index for the year 2005 is calculated excluding recreation clubs and "other groups". Social capital
} 
Table 2: Descriptive Data (Dependent Variable and Components)

\begin{tabular}{|c|c|c|c|}
\hline & $(1990)$ & $(1997)$ & $(2005)$ \\
\hline \multirow[t]{2}{*}{ Social capital } & 0.001 & 0.001 & $0.000^{* * *}$ \\
\hline & $(1.350)$ & $(1.298)$ & $(1.646)$ \\
\hline \multirow[t]{2}{*}{ Bowling centers } & 1.910 & 1.766 & 1.490 \\
\hline & $(4.671)$ & $(3.954)$ & $(3.106)$ \\
\hline \multirow[t]{2}{*}{ Civic associations } & 12.513 & 11.489 & 10.097 \\
\hline & $(34.927)$ & $(30.602)$ & $(24.765)$ \\
\hline \multirow[t]{2}{*}{ Gyms } & 2.444 & 3.541 & 10.161 \\
\hline & $(7.980)$ & $(11.874)$ & $(30.806)$ \\
\hline \multirow[t]{2}{*}{ Golf courses } & 0.888 & 1.949 & 3.825 \\
\hline & $(2.270)$ & $(3.854)$ & $(7.269)$ \\
\hline \multirow[t]{2}{*}{ Religious organizations } & 40.979 & 50.711 & 54.982 \\
\hline & $(87.040)$ & $(106.072)$ & $(116.530)$ \\
\hline \multirow[t]{2}{*}{ Sports clubs } & 0.288 & 0.623 & 0.244 \\
\hline & $(1.662)$ & $(2.877)$ & $(1.038)$ \\
\hline \multirow[t]{2}{*}{ Recreation clubs } & 4.172 & 4.779 & \\
\hline & $(10.119)$ & $(11.758)$ & \\
\hline \multirow[t]{2}{*}{ Political groups } & 0.495 & 0.578 & 0.950 \\
\hline & $(2.112)$ & $(2.650)$ & $(4.442)$ \\
\hline \multirow[t]{2}{*}{ Professional groups } & 1.670 & 2.499 & 2.407 \\
\hline & $(7.268)$ & $(10.465)$ & $(11.259)$ \\
\hline \multirow[t]{2}{*}{ Business groups } & 3.879 & 4.396 & 5.572 \\
\hline & $(13.131)$ & $(14.004)$ & $(17.548)$ \\
\hline \multirow[t]{2}{*}{ Labor groups } & 6.071 & 6.008 & 5.132 \\
\hline & $(19.293)$ & $(18.067)$ & $(15.991)$ \\
\hline \multirow[t]{2}{*}{ Other groups } & 3.012 & 2.365916 & \\
\hline & $(8.028)$ & $(5.448)$ & \\
\hline \multirow[t]{2}{*}{ Total organizations } & 78.320 & 90.795 & 94.859 \\
\hline & $(188.472)$ & $(209.379)$ & $(218.882)$ \\
\hline \multirow[t]{2}{*}{ Census responses } & $66.666^{*}$ & $62.519^{* *}$ & 0.642 \\
\hline & $(8.213)$ & $(8.831)$ & $(0.089)$ \\
\hline \multirow[t]{2}{*}{ Non-profit organizations } & 40.674 & 42.131 & $446.417^{* * *}$ \\
\hline & $(152.390)$ & $(157.681)$ & $(1357.03)$ \\
\hline \multirow[t]{2}{*}{ Population } & 78832.7 & 84821.72 & $93837.78^{* * *}$ \\
\hline & $(262630.9)$ & $(275600.5)$ & $(304866.5)$ \\
\hline \multirow[t]{2}{*}{ Voting fraction } & 54.001 & 52.888 & $58.256^{* * *}$ \\
\hline & $(10.851)$ & $(9.805)$ & $(9.577)$ \\
\hline \multirow[t]{2}{*}{ Voting fraction (2nd) } & 60.265 & & \\
\hline & $(10.210)$ & & \\
\hline
\end{tabular}

All variables have a sample size of 3110 unless otherwise indicated by asterisks. Includes standard deviation in parenthesis.

${ }^{*} \mathrm{~N}=2434,{ }^{* *} \mathrm{~N}=3066,{ }^{* * *} \mathrm{~N}=3107$ 
Table 3: Description of Independent Variables

\begin{tabular}{lc}
\hline \hline Name & Description/Definition \\
\hline Ethnic Fractionalization & Level of Diversity \\
Racial Dominance & Level of Dominance by the majority racial group \\
Black Proportion & Fraction of population That identifies as black \\
White Proportion & Fraction of population that identifies as white \\
Latino Proportion & Fraction of population that identifies as Latino or Hispanic \\
Asian Proportion & Fraction of population that identifies as Asian \\
Income Per Capita & Personal income per capita \\
Education Level & Percent of over 25 population with a Bachelor's Degree \\
Family Households & Percent of total households that are family households \\
$\begin{array}{l}\text { Median Age } \\
\text { Square of Median Age }\end{array}$ & Median age \\
Is the county urban? & Square of median age variable \\
Population Density & 1 if population is greater than 2500, 0 otherwise \\
Residence Time & Population per square mile \\
Working Women & Time resident spends in a given county \\
\hline
\end{tabular}

\section{Methodology}

\section{Econometric Model}

Using Ordinary Least Squares (OLS) estimates of Equation (2), we address our initial question as to the time difference in the statistical impact of ethnic diversity on social capital:

$$
S_{c t}=\beta_{0 t}+\beta_{1 t} e_{c t}+\sum_{j=1}^{J} \delta_{j t} z_{j c t}+\epsilon_{c t}
$$

In equation (2) $\mathrm{S}$ is social capital in county $\mathrm{c}$ in year t, e is ethnic fractionization in county $\mathrm{c}$ in year $\mathrm{t}, z_{j c t}$ are additional explanatory/control variables $(j=1, \ldots ., J)$ that could affect social capital at the county level and $\epsilon$ is the error term. In our preliminary regressions we use the following control variables: income per capita in the county, average education in the county, the number of family households in the county, a dummy variable delineating urban or rural counties, the median age of individuals in the country and a quadratic variable on median age. We derive estimates of $\beta_{1}$ and other parameters for $\mathrm{t}=1990,1999$ and 2005. These estimates are then examined for statistical difference. ${ }^{9}$

\footnotetext{
${ }^{9}$ It is important to note that we could have also tested for time differences in $\beta_{1}$ by pooling all the data together and interacting ethnic fractionalization with time. However,
} 
Table 4: Descriptive Data (Independent Variables)

\begin{tabular}{|c|c|c|c|}
\hline & $(1990)$ & $(1997)$ & $(2005)$ \\
\hline \multirow[t]{2}{*}{ Ethnic Fractionalization } & 0.183 & $0.208^{* * *}$ & $0.225^{* * *}$ \\
\hline & $(0.177)$ & $(0.177)$ & $(0.177)$ \\
\hline \multirow[t]{2}{*}{ Racial Dominance } & 0.876 & $0.861^{* * *}$ & $0.850^{* * *}$ \\
\hline & $(0.141)$ & $(0.141)$ & $(0.141)$ \\
\hline \multirow[t]{2}{*}{ Black Proportion } & 0.086 & $0.088^{* * *}$ & $0.088^{* * *}$ \\
\hline & $(0.144)$ & $(0.145)$ & $(0.142)$ \\
\hline \multirow[t]{2}{*}{ Latino Proportion } & 0.039 & $0.051^{* * *}$ & $0.060^{* * *}$ \\
\hline & $(0.083)$ & $(0.081)$ & $(0.084)$ \\
\hline \multirow[t]{2}{*}{ White Proportion } & 0.869 & $0.854^{* * *}$ & $0.843^{* * *}$ \\
\hline & $(0.158)$ & $(0.159)$ & $(0.159)$ \\
\hline \multirow[t]{2}{*}{ Asian Proportion } & 0.006 & $0.008^{* * *}$ & $0.009^{* * *}$ \\
\hline & $(0.012)$ & $(0.014)$ & $(0.016)$ \\
\hline \multirow[t]{2}{*}{ Income Per Capita } & 11122.81 & 17476.74 & -263735 \\
\hline & $(2681.445)$ & $(3956.538)$ & $(1.59 \mathrm{e} 07)$ \\
\hline \multirow[t]{2}{*}{ Education Level } & 13.475 & 16.493 & 18.647 \\
\hline & $(6.577)$ & $(7.809)$ & $(8.528)$ \\
\hline \multirow[t]{2}{*}{ Family Households } & 73.580 & $70.659^{* *}$ & $68.417^{* * *}$ \\
\hline & $(4.664)$ & $(4.801)$ & $(5.339)$ \\
\hline \multirow[t]{2}{*}{ Median Age } & 34.407 & 37.354 & 40.329 \\
\hline & $(3.611)$ & $(4.078)$ & $(5.178)$ \\
\hline \multirow[t]{2}{*}{ Square of Median Age } & 1196.867 & 1411.925 & 1653.246 \\
\hline & $(253.259)$ & $(296.384)$ & $(407.369)$ \\
\hline \multirow[t]{2}{*}{ Urban } & 0.963 & 0.965 & 0.960 \\
\hline & $(0.189)$ & $(0.185)$ & $(0.196)$ \\
\hline \multirow[t]{2}{*}{ Population Density } & 221.022 & $238.955^{* *}$ & $253.655^{* * *}$ \\
\hline & $(1438.214)$ & $(1649.197)$ & $(1735.426)$ \\
\hline \multirow[t]{2}{*}{ Residence Time } & $-33.381^{*}$ & $-44.520^{* * *}$ & $282.662^{* * * *}$ \\
\hline & $(6522.952)$ & $(3829.71)$ & $(8409.171)$ \\
\hline \multirow[t]{2}{*}{ Working Women } & $20.451^{* *}$ & $22.139^{* *}$ & $22.612^{* * *}$ \\
\hline & $(2.954)$ & $(3.010)$ & $(3.105)$ \\
\hline
\end{tabular}

All variables have a sample size of 3110 unless otherwise indicated by the asterisks.

Includes standard deviation in parenthesis

${ }^{*} \mathrm{~N}=3109,{ }^{* *} \mathrm{~N}=3108,{ }^{* * *} \mathrm{~N}=3107,{ }^{* * * *} \mathrm{~N}=3106$ 
The OLS estimation of the impact of ethnic fractionalization using equation (2) can lead to biased estimates given the potential endogenous nature of the ethnic fractionalization variable. Specifically, our parameter of interest could suffer from omitted variable bias if there is an unobservable determinant of social capital also correlated with ethnic fractionalization. For example, we do not control for the differences in institutions or policies across states. These institutions/policies may have produced lower levels of trust across the population and hence lower levels of social capital. At the same time, the level of ethnic fractionalization in a state could also be correlated with past institutions within a state. We reduce the likelihood of this potential source of bias in the estimation of $\beta_{1}$ by introducing further control variables. Most important of these controls is the introduction of state fixed effects. By including state fixed effects in the analysis, we control for any factor that is unique about a state (including past institutions and policies) that affects social capital. Although we are confident that the inclusion of state fixed effects attenuates bias in our estimates, it is possible to argue that even within states, there exists an omitted variable that is correlated with ethnic fractionalization across counties and also correlated with social capital accumulation. While we are unable to identify such a variable, we cannot rule out this possibility. However, in addressing our first question we are not overly concerned with deriving consistent estimates of the impact of ethnic fractionalization. Instead, testing for time differences in the impact of ethnic fractionalization depends on deriving a consistent estimate of the change in $\beta_{1}$ between 1990 and 1999 and between 1999 and 2005. If we assume that the potential bias in our estimate of $\beta_{1}$ is time invariant, then our estimate of these changes will be consistent even though parameter estimates could potentially be biased or inconsistent.

To address our second question, we estimate a pooled regression using Equation (3) and similar controls as those used for the initial estimation process. The only difference in variables is the inclusion of a dummy variable for survey period and an extra variable for racial dominance which we use to test for evidence of the conflict and hunker-down theories. We discuss in detail how we test for evidence of these theories below. ${ }^{10}$

given the length of time that has elapsed between each survey year, assuming other parameters in the social capital model do not change over time might not be appropriate. Also, the yearly regression can also be used to find support or lack thereof for the three theories espoused by Putman (2007) but our preference is to focus on the analysis pooling all the data together for our second question.

${ }^{10}$ It is important to mention that we can also attempt to test for evidence of the aforementioned theories by estimating our model using each survey year separately versus pooled. Though we also present these OLS results in section 6 for completeness, we do 


$$
S_{c t}=\beta_{0}+\beta_{1} e_{c t}+\sum_{j=1}^{J} \phi_{j} z_{j c t}+\epsilon_{c t}
$$

The tests of the three theories rely heavily on a reliable estimate of $\beta_{1}$. Therefore, issues of possible endogeneity are of significant concern. To attenuate potential bias in estimating $\beta_{1}$, we exploit the panel nature of our data and make use of a fixed effects model highlighted in equation (4).

$$
S_{c t}=\lambda Z_{c t}+\beta_{1} e_{c t}+\theta_{c}+\epsilon_{c t}
$$

In equation (4), $\theta_{c}$ is the individual county level effect and $\mathrm{Z}$ is a vector of all the control variables we use that vary across county and time. We also include our year dummies in $\mathrm{Z}$ although they vary solely across time. By exploiting a fixed effect panel model specification, our effects are identified over variation within the county. This eliminates possible residual selection across counties that could have biased estimates using the pooled crosssectional specification with state level fixed effects, estimated using OLS. While it is still possible to argue that the fixed effects model is threatened by within unit time varying unobservables, it is difficult to provide a compelling story that conditional on the variables we include in our analysis, that there is still an omitted variable that changes within a county over time that affects social capital and is correlated with ethnic fractionalization in the county. ${ }^{11}$

\section{Testing Putman's Social Network Models}

The contact theory suggests that greater levels of diversity leads to increased social capital in communities. To empirically test this hypothesis we focus on the estimated $\beta_{1}$ derived using both the pooled OLS regression and the fixed effect model. Our null hypothesis is $\beta_{1} \leq 0$. We reject our null hypothesis if $\beta_{1}>0$ suggesting that our results are consistent with the contact hypothesis.

Failing to reject the null means that either the conflict theory or hunkerdown theory is relevant.

To identify which of the 2 other theories is relevant if we fail to reject our null hypothesis, we add another variable, racial dominance, to our estimation model.

not discuss these results given yearly estimates can be biased and inference in that scenario is problematic.

${ }^{11}$ One potential drawback of using the fixed effect model with few time period is the limited variation over which potential effects are being identified. 
The racial dominance variable captures indirectly how the dominant ethnic group in a community responds to its own group conditional on the ethnic diversity of the community. This could provide evidence for either theories. Recall that the implication of conflict theory is that greater levels of diversity would lead to less social capital in a given community due to lack of trust and conflicts between the different ethnic groups. However, if one ethnic group is particularly dominant in terms of size and/or the infusion of a different ethnic group is particularly small then the impact on social capital may be negligible. Empirically if our estimate for $\beta_{1}<0$ and $\beta_{\text {Racial Dominance }} \geq 0$, then our results are consistent with the conflict theory.

The hunker-down theory suggests similar effects of diversity as the conflict theory. However, unlike the conflict theory, the hunker-down theory suggests that not only does increased diversity lead to reduced trust across ethnic groups, it also creates a reduction of in-group trust, in effect reducing social capital even more. Empirically, if the coefficient for ethnic fractionalization is negative and significant, while the coefficient for racial dominance is also negative and significant, then our results are consistent with the hunker-down theory i.e., $\beta_{1}<0$ and $\beta_{\text {Racial Dominance }}<0$.

\section{Results}

Table (5) provides a summary of the results from estimating Equation (2) using OLS and a limited set of controls. These results serve as our baseline estimate of possible effects. Table (6) also summarizes the results from estimating Equation (2), including additional controls. In the results summarized in Table (7) we include state level dummies which diminish selection and endogeneity biases. The inclusion of state level fixed effects in our estimation of Equation (2) is important because it allows the identification of the impact of ethnic fractionalization using variation across municipalities within a state at a particular period of time.

\subsection{Summary of Estimated Effects for Basic Control Vari- ables}

Before analyzing our results with respect to our two questions of interest, it is useful to examine expected relationships for control variables in our estimated models summarized in Tables (5-10). However Tables (7-10) provide the most complete information with regards to the estimated relationships as these tables' feature OLS specifications, including additional controls as well as our preferred fixed effect model. While some of the control variables 
generally hold intuitive relationships with social capital throughout all of the different specifications, the signs on some of our control varies varied across specification. In the instances where estimates of controls change significantly across specification, we focus on the estimated relationships in our preferred model.

The level of education shows a positive relationship with social capital across time. In effect, a population that holds proportionally more undergraduate degrees tends to have more social capital. Educated people are more likely to be employed in workplaces that place greater importance on teamwork and building social connections. We can also argue that skilled occupations are scalable and have more flexible working conditions, which allow more time to engage in the production of social capital.

Whether or not a community is urban shows a significant, negative relationship with social capital across time. Urban environments are generally perceived as less social, possibly due to higher crime or less social space.

Residence time, the approximate total time an individual spends in a city, shows a negative, but insignificant relationship with social capital. A possible reason for this is the difficulty in approximating residence time accurately. The percentage of working women shows a significant, positive relationship with social capital. This result suggests that more women in the workplace increases social capital, which corroborates the reasoning behind the relationships for level of education. The variables income per capita, percentage of family households and median age show different relationships depending on the model specification. Our preferred specification is summarized in Table (10). Results in Table (10) show an insignificant positive relationship between income per capita in a county and social capital. Further, the percentage of family households also shows a positive but insignificant relationship with social capital. A negative relationship between social capital and population density is also noted though also insignificant. Median age shows a negative, and significant relationship while the square of median age shows a positive significant relationship. This result suggests a nonlinear relationship between social capital formation and median age of individuals in a community. This result may also suggest that younger communities are not forming social capital through the traditional means captured by our social capital measures. However we do not infer from this result that younger communities are not forming social capital at all. ${ }^{12}$

\footnotetext{
${ }^{12}$ While the avid of social media and web-based social networking sites by younger generations today suggest social capital is being accumulated using different means, it is possible to argue that even before 2006, younger people were connecting and forming social network and social capital through other channels that are not captured in the RFG
} 


\section{Results: Testing for Time Differences}

Examination of columns (1) to (3) of Tables (5-7) is useful in addressing the impact of ethnic fractionalization across time. Notice that while results in Table (5) and (6) suggest time differences in the impact of ethnic fractionalization on social capital, this result is not robust. The inclusion of state fixed effects in Table (7) eliminates any time variation in the impact of ethnic fractionalization on social capital. We formally test for statistical difference in the estimates of the effect of ethnic fractionalization in 1990, 1997 and 2005. Our test leads a rejection of time differences in the relationship between social capital and ethnic fractionalization. Hence, we can infer that this relationship is stable over the evaluation period.

It is important to mention that the estimated effects of ethnic fractionalization could be biased even with the inclusion of state fixed effects. However, the estimate of the change in estimated impact of ethnic fractionalization is consistent and the inference valid as long as potential bias in our results are time invariant. ${ }^{13}$

\section{Results: Testing Putmans' Theories}

The second question, which provides the core of this research, use the empirical models highlighted above to search for evidence in support of either the contact, the conflict, and the hunker-down theories. In contrast to our test for time differences, there is a need to minimize bias in our estimated effects. Hence, though the results in tables (5-7) can be considered to test for evidence of these models, given the specifications summarized in these tables have limited controls and crosssectional analysis is more prone to biased estimated, we do not focus on these results in providing concrete evidence in favor of any theory.

To provide evidence of these theories we focus on the results in Tables (8-10) where our pooled regression results and fixed effect models are summarized. As noted above, our fixed effects model specification is our preferred model of analysis because it eliminates most sources of potential bias in estimated effects.

In Table (8) the estimated effect of ethnic fractionalization is negative across all six specifications. Which suggests that there is no evidence in

social capital measure.

${ }^{13}$ There is no reason to expect bias if it exists to be time varying. Hence, we are confident that on average, there were no time differences in the impact of ethnic fractionalization within the time frame we examined. 
Table 5: Initial Regression Results

\begin{tabular}{|c|c|c|c|c|c|c|}
\hline \multirow{3}{*}{$\begin{array}{l}\text { Dependent Variable: } \\
\text { Social Capital }\end{array}$} & $(1)$ & $(2)$ & $(3)$ & \multirow{3}{*}{$\begin{array}{c}(4) \\
\text { Conflict vs } \\
(1990)\end{array}$} & \multirow{3}{*}{$\begin{array}{c}(5) \\
\text { hunker-down } \\
(1997)\end{array}$} & \multirow{3}{*}{$\begin{array}{c}(6) \\
\text { Hypothesis } \\
(2005)\end{array}$} \\
\hline & \multicolumn{3}{|c|}{ Testing Contact Hypothesis } & & & \\
\hline & $(1990)$ & (1997) & $(2005)$ & & & \\
\hline Ethnic Fractionalization & $\begin{array}{l}-3.363^{* * *} \\
(-32.19)\end{array}$ & $\begin{array}{l}-2.606^{* * *} \\
(-25.91)\end{array}$ & $\begin{array}{l}-3.094^{* * *} \\
(-23.18)\end{array}$ & $\begin{array}{c}-8.871^{* * *} \\
(-17.40)\end{array}$ & $\begin{array}{c}-5.240^{* * *} \\
(-11.75)\end{array}$ & $\begin{array}{c}-6.190^{* * *} \\
(-10.53)\end{array}$ \\
\hline Racial Dominance & & & & $\begin{array}{c}-7.045^{* * *} \\
(-10.93)\end{array}$ & $\begin{array}{c}-3.359^{* * *} \\
(-6.12)\end{array}$ & $\begin{array}{c}-3.909^{* * *} \\
(-5.50)\end{array}$ \\
\hline Income Per Capita & $\begin{array}{c}-0.000^{* *} \\
(-3.17)\end{array}$ & $\begin{array}{l}-0.000 \\
(-0.61)\end{array}$ & $\begin{array}{c}0.000^{* * *} \\
(4.49)\end{array}$ & $\begin{array}{l}-0.000 \\
(-0.78)\end{array}$ & $\begin{array}{l}0.000 \\
(0.42)\end{array}$ & $\begin{array}{c}0.000^{* * *} \\
(4.91)\end{array}$ \\
\hline Education Level & $\begin{array}{l}0.043^{* * *} \\
(6.32)\end{array}$ & $\begin{array}{l}0.051^{* * *} \\
(9.56)\end{array}$ & $\begin{array}{c}0.037^{* * *} \\
(12.68)\end{array}$ & $\begin{array}{c}0.040^{* * *} \\
(5.95)\end{array}$ & $\begin{array}{c}0.050^{* * *} \\
(9.41)\end{array}$ & $\begin{array}{c}0.041^{* * *} \\
(13.31)\end{array}$ \\
\hline Family Households & $\begin{array}{c}-0.079^{* * *} \\
(-12.56)\end{array}$ & $\begin{array}{c}-0.077^{* * *} \\
(-16.12)\end{array}$ & $\begin{array}{c}-0.068^{* * *} \\
(-12.39)\end{array}$ & $\begin{array}{c}-0.081^{* * *} \\
(-12.99)\end{array}$ & $\begin{array}{c}-0.078^{* * *} \\
(-16.13)\end{array}$ & $\begin{array}{c}-0.066^{* * *} \\
(-11.97)\end{array}$ \\
\hline Median Age & $\begin{array}{l}0.462^{* * *} \\
(6.99)\end{array}$ & $\begin{array}{l}0.223^{* * *} \\
(3.45)\end{array}$ & $\begin{array}{l}0.028 \\
(0.45)\end{array}$ & $\begin{array}{l}0.413^{* * *} \\
\quad(6.30)\end{array}$ & $\begin{array}{c}0.208^{* *} \\
(3.19)\end{array}$ & $\begin{array}{l}0.036 \\
(0.59)\end{array}$ \\
\hline Square of Median Age & $\begin{array}{c}-0.006^{* * *} \\
(-6.03)\end{array}$ & $\begin{array}{c}-0.002^{*} \\
(-2.55)\end{array}$ & $\begin{array}{l}0.001 \\
(0.73)\end{array}$ & $\begin{array}{c}-0.005^{* * *} \\
(-5.38)\end{array}$ & $\begin{array}{c}-0.002^{*} \\
(-2.34)\end{array}$ & $\begin{array}{l}0.000 \\
(0.58)\end{array}$ \\
\hline Urban & $\begin{array}{c}-0.740^{* * *} \\
(-4.91)\end{array}$ & $\begin{array}{c}-0.616^{* * *} \\
(-3.55)\end{array}$ & $\begin{array}{c}-1.453^{* * *} \\
(-5.80)\end{array}$ & $\begin{array}{c}-0.726^{* * *} \\
(-4.87)\end{array}$ & $\begin{array}{c}-0.618^{* * *} \\
(-3.59)\end{array}$ & $\begin{array}{c}-1.436^{* * *} \\
(-5.73)\end{array}$ \\
\hline Constant & $\begin{array}{l}-2.124 \\
(-1.59) \\
\end{array}$ & $\begin{array}{r}0.604 \\
(0.46) \\
\end{array}$ & $\begin{array}{c}3.932^{* *} \\
(3.14)\end{array}$ & $\begin{array}{c}5.782^{* * *} \\
(3.86)\end{array}$ & $\begin{array}{c}4.265^{* *} \\
(2.98)\end{array}$ & $\begin{array}{c}7.596^{* * *} \\
(5.56)\end{array}$ \\
\hline Observations & 3110 & 3107 & 3107 & 3110 & 3107 & 3107 \\
\hline
\end{tabular}


Table 6: Regression Results with Additional Control Variables

\begin{tabular}{|c|c|c|c|c|c|c|}
\hline \multirow{2}{*}{$\begin{array}{l}\text { Dependent Variable: } \\
\text { Social Capital }\end{array}$} & $(1)$ & $(2)$ & $(3)$ & \multirow{2}{*}{$\begin{array}{c}(4) \\
\text { Conflict vs. } \\
(1990)\end{array}$} & \multirow{2}{*}{$\begin{array}{c}(5) \\
\text { hunker-dowı } \\
(1997)\end{array}$} & \multirow{2}{*}{$\begin{array}{c}(6) \\
\text { Hypothesis } \\
\text { (2005) }\end{array}$} \\
\hline & \multicolumn{3}{|c|}{ Testing Contact Hypothesis } & & & \\
\hline Ethnic Fractionalization & $\begin{array}{c}-3.297^{* * *} \\
(-31.34)\end{array}$ & $\begin{array}{c}-2.239^{* * *} \\
(-19.79)\end{array}$ & $\begin{array}{c}-2.530^{* * *} \\
(-17.56)\end{array}$ & $\begin{array}{c}-8.980^{* * *} \\
(-17.65)\end{array}$ & $\begin{array}{c}-4.690^{* * *} \\
(-10.37)\end{array}$ & $\begin{array}{c}-5.317^{* * *} \\
(-9.09)\end{array}$ \\
\hline Racial Dominance & & & & $\begin{array}{c}-7.292^{* * *} \\
(-11.28)\end{array}$ & $\begin{array}{c}-3.113^{* * *} \\
(-5.65)\end{array}$ & $\begin{array}{c}-3.514^{* * *} \\
(-5.02)\end{array}$ \\
\hline Income Per Capita & $\begin{array}{c}-0.000^{* *} \\
(-2.96)\end{array}$ & $\begin{array}{c}-0.000^{* * *} \\
(-3.36)\end{array}$ & $\begin{array}{l}0.000 \\
(0.60)\end{array}$ & $\begin{array}{l}-0.000 \\
(-0.34)\end{array}$ & $\begin{array}{r}-0.000^{*} \\
(-2.18)\end{array}$ & $\begin{array}{l}0.000 \\
(1.07)\end{array}$ \\
\hline Education Level & $\begin{array}{c}0.042^{* * *} \\
(6.14)\end{array}$ & $\begin{array}{c}0.048^{* * *} \\
(8.87)\end{array}$ & $\begin{array}{c}0.011^{* *} \\
(2.88)\end{array}$ & $\begin{array}{l}0.038^{* * *} \\
(5.61)\end{array}$ & $\begin{array}{c}0.047^{* * *} \\
(8.69)\end{array}$ & $\begin{array}{c}0.016^{* * *} \\
(3.80)\end{array}$ \\
\hline Family Households & $\begin{array}{c}-0.078^{* * *} \\
(-11.75)\end{array}$ & $\begin{array}{c}-0.072^{* * *} \\
(-13.48)\end{array}$ & $\begin{array}{c}-0.067^{* * *} \\
(-12.77)\end{array}$ & $\begin{array}{c}-0.083^{* * *} \\
(-12.67)\end{array}$ & $\begin{array}{c}-0.073^{* * *} \\
(-13.76)\end{array}$ & $\begin{array}{c}-0.065^{* * *} \\
(-12.45)\end{array}$ \\
\hline Median Age & $\begin{array}{c}0.443^{* * *} \\
\quad(6.67)\end{array}$ & $\begin{array}{c}0.184^{* *} \\
(2.79)\end{array}$ & $\begin{array}{l}-0.068 \\
(-1.06)\end{array}$ & $\begin{array}{c}0.400^{* * *} \\
(6.05)\end{array}$ & $\begin{array}{c}0.172^{* *} \\
(2.59)\end{array}$ & $\begin{array}{l}-0.058 \\
(-0.92)\end{array}$ \\
\hline Square of Median Age & $\begin{array}{c}-0.005^{* * *} \\
(-5.64)\end{array}$ & $\begin{array}{l}-0.001 \\
(-1.66)\end{array}$ & $\begin{array}{l}0.002^{*} \\
(2.30)\end{array}$ & $\begin{array}{c}-0.005^{* * *} \\
(-5.11)\end{array}$ & $\begin{array}{l}-0.001 \\
(-1.53)\end{array}$ & $\begin{array}{l}0.002^{*} \\
(2.16)\end{array}$ \\
\hline Urban & $\begin{array}{c}-0.792^{* * *} \\
(-5.21)\end{array}$ & $\begin{array}{c}-0.649^{* * *} \\
(-3.76)\end{array}$ & $\begin{array}{c}-1.442^{* * *} \\
(-5.90)\end{array}$ & $\begin{array}{c}-0.769^{* * *} \\
(-5.10)\end{array}$ & $\begin{array}{c}-0.651^{* * *} \\
(-3.80)\end{array}$ & $\begin{array}{c}-1.427^{* * *} \\
(-5.84)\end{array}$ \\
\hline Population Density & $\begin{array}{l}-0.000 \\
(-1.93)\end{array}$ & $\begin{array}{l}-0.000 \\
(-1.55)\end{array}$ & $\begin{array}{r}-0.000^{*} \\
(-2.54)\end{array}$ & $\begin{array}{c}-0.000^{* *} \\
(-2.73)\end{array}$ & $\begin{array}{l}-0.000 \\
(-1.88)\end{array}$ & $\begin{array}{r}-0.000^{*} \\
(-2.51)\end{array}$ \\
\hline Residence Time & $\begin{array}{l}0.000 \\
(0.45)\end{array}$ & $\begin{array}{l}-0.000 \\
(-0.97)\end{array}$ & $\begin{array}{l}-0.000 \\
(-1.09)\end{array}$ & $\begin{array}{l}0.000 \\
(0.23)\end{array}$ & $\begin{array}{l}-0.000 \\
(-0.96)\end{array}$ & $\begin{array}{l}-0.000 \\
(-1.18)\end{array}$ \\
\hline Working Women & $\begin{array}{l}0.019 \\
(1.81)\end{array}$ & $\begin{array}{c}0.072^{* * *} \\
(6.68)\end{array}$ & $\begin{array}{c}0.119^{* * *} \\
(10.17)\end{array}$ & $\begin{array}{l}0.008 \\
(0.78)\end{array}$ & $\begin{array}{c}0.067^{* * *} \\
(6.23)\end{array}$ & $\begin{array}{c}0.117^{* * *} \\
(9.92)\end{array}$ \\
\hline Constant & $\begin{array}{l}-2.203 \\
(-1.62)\end{array}$ & $\begin{array}{l}-0.440 \\
(-0.31)\end{array}$ & $\begin{array}{l}3.240^{*} \\
(2.37)\end{array}$ & $\begin{array}{c}6.225^{* * *} \\
(4.06)\end{array}$ & $\begin{array}{c}3.076^{*} \\
(1.99)\end{array}$ & $\begin{array}{c}6.542^{* * *} \\
(4.46)\end{array}$ \\
\hline Observations & 3108 & 3106 & 3106 & 3108 & 3106 & 3106 \\
\hline
\end{tabular}

$t$ statistics in parentheses

${ }^{*} p<0.05,{ }^{* *} p<0.01,{ }^{* * *} p<0.001$

Regression models 4-6 are testing the Conflict and Hunker-Down Hypotheses 
Table 7: Regression Results with State Dummy Variables

\begin{tabular}{|c|c|c|c|c|c|c|}
\hline \multirow{2}{*}{$\begin{array}{l}\text { Dependent Variable: } \\
\text { Social Capital }\end{array}$} & $(1)$ & $(2)$ & (3) & \multirow{2}{*}{$\begin{array}{c}(4) \\
\text { Conflict vs. } \\
(1990)\end{array}$} & \multirow{2}{*}{$\begin{array}{l}(5) \\
\text { hunker-down } \\
(1997)\end{array}$} & \multirow{2}{*}{$\begin{array}{c}(6) \\
\text { Hypothesis } \\
(2005)\end{array}$} \\
\hline & $\begin{array}{l}\text { Testing } \\
(1990)\end{array}$ & $\begin{array}{l}\text { Contact Hy } \\
\text { (1997) }\end{array}$ & $\begin{array}{l}\text { othesis } \\
(2005)\end{array}$ & & & \\
\hline Ethnic Fractionalization & $\begin{array}{c}-0.427^{* *} \\
(-3.14)\end{array}$ & $\begin{array}{c}-0.457^{* *} \\
(-2.80)\end{array}$ & $\begin{array}{l}-0.497^{*} \\
(-2.54)\end{array}$ & $\begin{array}{c}-2.884^{* * *} \\
(-5.98)\end{array}$ & $\begin{array}{l}-0.899 \\
(-1.93)\end{array}$ & $\begin{array}{l}-0.963 \\
(-1.76)\end{array}$ \\
\hline Racial Dominance & & & & $\begin{array}{c}-3.017^{* * *} \\
(-5.25)\end{array}$ & $\begin{array}{l}-0.544 \\
(-1.02)\end{array}$ & $\begin{array}{l}-0.572 \\
(-0.92)\end{array}$ \\
\hline Income Per Capita & $\begin{array}{l}-0.000 \\
(-0.66)\end{array}$ & $\begin{array}{l}0.000 \\
(0.15)\end{array}$ & $\begin{array}{c}-0.000^{* *} \\
(-2.66)\end{array}$ & $\begin{array}{l}0.000 \\
(0.31)\end{array}$ & $\begin{array}{l}0.000 \\
(0.31)\end{array}$ & $\begin{array}{c}-0.000^{* *} \\
(-2.63)\end{array}$ \\
\hline Education Level & $\begin{array}{c}0.033^{* * *} \\
(5.25)\end{array}$ & $\begin{array}{c}0.038^{* * *} \\
(6.48)\end{array}$ & $\begin{array}{c}0.022^{* * *} \\
(4.84)\end{array}$ & $\begin{array}{l}0.030^{* * *} \\
(4.80)\end{array}$ & $\begin{array}{c}0.037^{* * *} \\
(6.36)\end{array}$ & $\begin{array}{l}0.023^{* * *} \\
(4.92)\end{array}$ \\
\hline Family Households & $\begin{array}{c}-0.045^{* * *} \\
(-7.59)\end{array}$ & $\begin{array}{c}-0.055^{* * *} \\
(-10.35)\end{array}$ & $\begin{array}{c}-0.051^{* * *} \\
(-10.12)\end{array}$ & $\begin{array}{c}-0.048^{* * *} \\
(-8.13)\end{array}$ & $\begin{array}{c}-0.055^{* * *} \\
(-10.39)\end{array}$ & $\begin{array}{c}-0.051^{* * *} \\
(-10.07)\end{array}$ \\
\hline Median Age & $\begin{array}{c}0.477^{* * *} \\
(8.68)\end{array}$ & $\begin{array}{c}0.236^{* * *} \\
(4.33)\end{array}$ & $\begin{array}{c}0.132^{*} \\
(2.23)\end{array}$ & $\begin{array}{c}0.460^{* * *} \\
(8.52)\end{array}$ & $\begin{array}{l}0.235^{* * *} \\
(4.30)\end{array}$ & $\begin{array}{c}0.133^{*} \\
(2.25)\end{array}$ \\
\hline Square of Median Age & $\begin{array}{c}-0.005^{* * *} \\
(-6.78)\end{array}$ & $\begin{array}{c}-0.002^{* *} \\
(-3.05)\end{array}$ & $\begin{array}{l}-0.000 \\
(-0.67)\end{array}$ & $\begin{array}{c}-0.005^{* * *} \\
(-6.67)\end{array}$ & $\begin{array}{c}-0.002^{* *} \\
(-3.04)\end{array}$ & $\begin{array}{l}-0.001 \\
(-0.70)\end{array}$ \\
\hline Urban & $\begin{array}{c}-0.570^{* * *} \\
(-4.14)\end{array}$ & $\begin{array}{c}-0.435^{* *} \\
(-2.78)\end{array}$ & $\begin{array}{c}-0.871^{* * *} \\
(-3.77)\end{array}$ & $\begin{array}{c}-0.562^{* * *} \\
(-4.12)\end{array}$ & $\begin{array}{c}-0.435^{* *} \\
(-2.78)\end{array}$ & $\begin{array}{c}-0.870^{* * *} \\
(-3.77)\end{array}$ \\
\hline Population Density & $\begin{array}{c}-0.000^{* *} \\
(-2.63)\end{array}$ & $\begin{array}{c}-0.000^{*} \\
(-2.16)\end{array}$ & $\begin{array}{c}-0.000^{*} \\
(-2.30)\end{array}$ & $\begin{array}{c}-0.000^{* *} \\
(-2.84)\end{array}$ & $\begin{array}{c}-0.000^{*} \\
(-2.18)\end{array}$ & $\begin{array}{r}-0.000^{*} \\
(-2.28)\end{array}$ \\
\hline Residence Time & $\begin{array}{l}0.000 \\
(1.26)\end{array}$ & $\begin{array}{l}-0.000 \\
(-0.69)\end{array}$ & $\begin{array}{l}-0.000 \\
(-0.25)\end{array}$ & $\begin{array}{l}0.000 \\
(1.15)\end{array}$ & $\begin{array}{l}-0.000 \\
(-0.68)\end{array}$ & $\begin{array}{l}-0.000 \\
(-0.27)\end{array}$ \\
\hline Working Women & $\begin{array}{c}0.028^{*} \\
(2.35)\end{array}$ & $\begin{array}{c}0.033^{* *} \\
(2.62)\end{array}$ & $\begin{array}{c}0.049^{* *} \\
(3.00)\end{array}$ & $\begin{array}{c}0.028^{*} \\
(2.38)\end{array}$ & $\begin{array}{c}0.033^{* *} \\
(2.61)\end{array}$ & $\begin{array}{c}0.049^{* *} \\
(3.01)\end{array}$ \\
\hline Constant & $\begin{array}{c}-7.855^{* * *} \\
(-6.77) \\
\end{array}$ & $\begin{array}{c}-3.320^{*} \\
(-2.56) \\
\end{array}$ & $\begin{array}{l}-2.342 \\
(-1.69) \\
\end{array}$ & $\begin{array}{c}-4.293^{* *} \\
(-3.28) \\
\end{array}$ & $\begin{array}{l}-2.706 \\
(-1.92) \\
\end{array}$ & $\begin{array}{l}-1.790 \\
(-1.21) \\
\end{array}$ \\
\hline Observations & 3108 & 3106 & 3106 & 3108 & 3106 & 3106 \\
\hline
\end{tabular}

$t$ statistics in parentheses
${ }^{*} p<0.05,{ }^{* *} p<0.01,{ }^{* * *} p<0.001$

Regression models 4-6 are testing the Conflict and Hunker-Down Hypotheses 
our data for contact theory. On the other hand, as we fail to reject our null hypothesis, our results suggest that our data is consistent with either a conflict or a hunker-down theory. The lack of evidence for the contact theory is also confirmed in our preferred model, Table (10).

To decipher whether conflict or hunker-down theory is consistent with the data, we turn first to the results summarized in Table (9). Notice two things from Table (9), the estimated effect of ethnic fractionalization changes drastically with the inclusion of the ethnic dominance variable compared to estimate in Table (8). Secondly, we find that the racial dominance variable is negative and significant which is suggestive of the hunker-down theory. We examine our preferred model, Table (10) and find that both results are verified. Estimates on ethnic fractionalization in our fixed effect model also changes drastically with the inclusion of the racial dominance variable and the estimated impacts of this variable is also negative and significant suggesting our data is consistent with the hunker-down theory.

The drastic change in the estimated impact of ethnic fractionalization with the inclusion of the ethnic dominance variable raises significant concerns about potential multicollinearity. Specifically, the nonsignificant estimates on ethnic fractionalization in Table (7) columns (5) and (6) as well as the significant changes in the magnitude of the estimate on ethnic fractionalization from the pooled regression and fixed effects models when the racial dominance variable is included (Tables (9) and (10)) provides reason for caution.

Given the potential problem with the earlier estimation when including racial dominance, we hesitate to conclude that the results in columns (3)(6) of Tables (5-7), Tables (9) and Table (10) columns (3) and (4) provides convincing evidence supporting the hunker-down theory. Given this concern, we carefully examining the independence of racial dominance and ethnic fractionalization in our model. We investigate the potential collinearity by directly estimating the correlation coefficient between the two variables. Table (11) highlights the correlation coefficient between the two variables, as well as other correlations that we discuss in the next section.

Table (11) confirms that ethnic fractionalization is highly correlated with racial dominance. Given that ethnic fractionalization is highly negatively correlated with both social capital and racial dominance, the estimated effect of both ethnic fractionalization and racial dominance on social capital will be imprecise. To test Putnam's theories despite this obstacle, we replace the ethnic fractionalization variable with a suitable proxy. This proxy must be correlated strongly with ethnic fractionalization, but not as strongly correlated with racial dominance. Table (11) summarizes potential choices 
Table 8: Pooled Regression Results (Testing Contact Hypothesis)

\begin{tabular}{|c|c|c|c|c|c|c|}
\hline $\begin{array}{l}\text { Dependent Variable: } \\
\text { Social Capital }\end{array}$ & $(1)$ & $(2)$ & $(3)$ & (4) & $(5)$ & (6) \\
\hline Ethnic Fractionalization & $\begin{array}{c}-3.022^{* * *} \\
(-45.92)\end{array}$ & $\begin{array}{c}-0.646^{* * *} \\
(-6.95)\end{array}$ & $\begin{array}{c}-2.825^{* * *} \\
(-40.92)\end{array}$ & $\begin{array}{c}-0.555^{* * *} \\
(-5.71)\end{array}$ & $\begin{array}{c}-2.769^{* * *} \\
(-39.85)\end{array}$ & $\begin{array}{c}-0.424^{* * *} \\
(-4.35)\end{array}$ \\
\hline Income Per Capita & $\begin{array}{l}0.000^{* * *} \\
(6.08)\end{array}$ & $\begin{array}{c}-0.000^{* * *} \\
(-3.35)\end{array}$ & $\begin{array}{c}0.000^{* * *} \\
(4.11)\end{array}$ & $\begin{array}{c}-0.000^{* * *} \\
(-3.84)\end{array}$ & $\begin{array}{c}0.000^{* * *} \\
(3.87)\end{array}$ & $\begin{array}{c}-0.000^{* * *} \\
(-3.80)\end{array}$ \\
\hline Education Level & $\begin{array}{c}0.039^{* * *} \\
(21.82)\end{array}$ & $\begin{array}{c}0.037^{* * *} \\
(19.45)\end{array}$ & $\begin{array}{c}0.024^{* * *} \\
(10.47)\end{array}$ & $\begin{array}{c}0.027^{* * *} \\
(10.35)\end{array}$ & $\begin{array}{c}0.025^{* * *} \\
(10.89)\end{array}$ & $\begin{array}{c}0.028^{* * *} \\
(10.75)\end{array}$ \\
\hline Family Households & $\begin{array}{c}-0.074^{* * *} \\
(-23.76)\end{array}$ & $\begin{array}{c}-0.048^{* * *} \\
(-15.76)\end{array}$ & $\begin{array}{c}-0.072^{* * *} \\
(-23.85)\end{array}$ & $\begin{array}{c}-0.048^{* * *} \\
(-16.18)\end{array}$ & $\begin{array}{c}-0.074^{* * *} \\
(-24.34)\end{array}$ & $\begin{array}{c}-0.049^{* * *} \\
(-16.72)\end{array}$ \\
\hline Median Age & $\begin{array}{c}0.108^{* *} \\
(3.24)\end{array}$ & $\begin{array}{l}0.174^{* * *} \\
\quad(5.85)\end{array}$ & $\begin{array}{l}0.053 \\
(1.55)\end{array}$ & $\begin{array}{l}0.150^{* * *} \\
(5.04)\end{array}$ & $\begin{array}{l}0.059 \\
(1.72)\end{array}$ & $\begin{array}{l}0.155^{* * *} \\
(5.19)\end{array}$ \\
\hline Square of Median Age & $\begin{array}{l}-0.001 \\
(-1.15)\end{array}$ & $\begin{array}{c}-0.001^{* *} \\
(-2.89)\end{array}$ & $\begin{array}{l}0.000 \\
(0.56)\end{array}$ & $\begin{array}{r}-0.001^{*} \\
(-2.00)\end{array}$ & $\begin{array}{l}0.000 \\
(0.39)\end{array}$ & $\begin{array}{r}-0.001^{*} \\
(-2.13)\end{array}$ \\
\hline Urban & $\begin{array}{c}-0.967^{* * *} \\
(-8.40)\end{array}$ & $\begin{array}{c}-0.607^{* * *} \\
(-5.66)\end{array}$ & $\begin{array}{c}-1.048^{* * *} \\
(-9.21)\end{array}$ & $\begin{array}{c}-0.643^{* * *} \\
(-6.05)\end{array}$ & $\begin{array}{c}-1.045^{* * *} \\
(-9.18)\end{array}$ & $\begin{array}{c}-0.646^{* * *} \\
(-6.08)\end{array}$ \\
\hline 1997.Year & $\begin{array}{c}-0.463^{* * *} \\
(-16.10)\end{array}$ & $\begin{array}{c}-0.501^{* * *} \\
(-21.23)\end{array}$ & $\begin{array}{c}-0.529^{* * *} \\
(-17.64)\end{array}$ & $\begin{array}{c}-0.548^{* * *} \\
(-20.90)\end{array}$ & $\begin{array}{c}-0.539^{* * *} \\
(-17.97)\end{array}$ & $\begin{array}{c}-0.561^{* * *} \\
(-21.39)\end{array}$ \\
\hline 2005.Year & $\begin{array}{c}-0.866^{* * *} \\
(-23.49)\end{array}$ & $\begin{array}{c}-0.926^{* * *} \\
(-29.25)\end{array}$ & $\begin{array}{c}-0.950^{* * *} \\
(-25.05)\end{array}$ & $\begin{array}{c}-0.984^{* * *} \\
(-28.44)\end{array}$ & $\begin{array}{c}-0.966^{* * *} \\
(-25.44)\end{array}$ & $\begin{array}{c}-1.006^{* * *} \\
(-28.99)\end{array}$ \\
\hline Residence Time & & & $\begin{array}{l}-0.000 \\
(-1.29)\end{array}$ & $\begin{array}{l}-0.000 \\
(-0.38)\end{array}$ & $\begin{array}{l}-0.000 \\
(-1.27)\end{array}$ & $\begin{array}{l}-0.000 \\
(-0.43)\end{array}$ \\
\hline Working Women & & & $\begin{array}{c}0.064^{* * *} \\
(10.27)\end{array}$ & $\begin{array}{c}0.040^{* * *} \\
(5.10)\end{array}$ & $\begin{array}{c}0.064^{* * *} \\
(10.29)\end{array}$ & $\begin{array}{c}0.040^{* * *} \\
(5.07)\end{array}$ \\
\hline Population Density & & & & & $\begin{array}{c}-0.000^{* * *} \\
(-3.92)\end{array}$ & $\begin{array}{c}-0.000^{* * *} \\
(-3.73)\end{array}$ \\
\hline Constant & $\begin{array}{c}3.287^{* * *} \\
(4.81)\end{array}$ & $\begin{array}{c}-1.609^{*} \\
(-2.48)\end{array}$ & $\begin{array}{c}3.075^{* * *} \\
(4.40)\end{array}$ & $\begin{array}{c}-1.905^{* *} \\
(-2.82)\end{array}$ & $\begin{array}{c}3.077^{* * *} \\
(4.39)\end{array}$ & $\begin{array}{c}-1.911^{* *} \\
(-2.82)\end{array}$ \\
\hline State Dummy Variables Used? & No & Yes & No & Yes & No & Yes \\
\hline Observations & 9324 & 9324 & 9320 & 9320 & 9320 & 9320 \\
\hline
\end{tabular}

${ }^{*} p<0.05,{ }^{* *} p<0.01,{ }^{* * *} p<0.001$ 
Table 9: Pooled Regression Results (Testing hunker-down Theory)

\begin{tabular}{|c|c|c|c|c|c|c|}
\hline $\begin{array}{l}\text { Dependent Variable: } \\
\text { Social Capital }\end{array}$ & (1) & $(2)$ & (3) & (4) & (5) & (6) \\
\hline Ethnic Fractionalization & $\begin{array}{c}-6.822^{* * *} \\
(-22.92)\end{array}$ & $\begin{array}{c}-1.465^{* * *} \\
(-5.03)\end{array}$ & $\begin{array}{c}-6.615^{* * *} \\
(-22.18)\end{array}$ & $\begin{array}{c}-1.576^{* * *} \\
(-5.43)\end{array}$ & $\begin{array}{c}-6.668^{* * *} \\
(-22.52)\end{array}$ & $\begin{array}{c}-1.570^{* * *} \\
(-5.48)\end{array}$ \\
\hline Racial Dominance & $\begin{array}{c}-4.840 * * * \\
(-13.26)\end{array}$ & $\begin{array}{c}-1.003^{* *} \\
(-2.98)\end{array}$ & $\begin{array}{c}-4.828 * * * \\
(-13.14)\end{array}$ & $\begin{array}{c}-1.254^{* * *} \\
(-3.69)\end{array}$ & $\begin{array}{c}-4.979^{* * *} \\
(-13.64)\end{array}$ & $\begin{array}{c}-1.414^{* * *} \\
\quad(-4.23)\end{array}$ \\
\hline Income Per Capita & $\begin{array}{l}0.000^{* * *} \\
(6.75)\end{array}$ & $\begin{array}{c}-0.000^{* *} \\
(-3.27)\end{array}$ & $\begin{array}{c}0.000^{* * *} \\
(4.79)\end{array}$ & $\begin{array}{c}-0.000^{* * *} \\
(-3.76)\end{array}$ & $\begin{array}{c}0.000^{* * *} \\
(4.53)\end{array}$ & $\begin{array}{c}-0.000^{* * *} \\
(-3.71)\end{array}$ \\
\hline Education Level & $\begin{array}{c}0.045^{* * *} \\
(23.74)\end{array}$ & $\begin{array}{c}0.038^{* * *} \\
(19.48)\end{array}$ & $\begin{array}{c}0.029^{* * *} \\
(12.58)\end{array}$ & $\begin{array}{c}0.028^{* * *} \\
(10.73)\end{array}$ & $\begin{array}{c}0.031^{* * *} \\
(13.11)\end{array}$ & $\begin{array}{c}0.029^{* * *} \\
(11.18)\end{array}$ \\
\hline Family Households & $\begin{array}{c}-0.072^{* * *} \\
(-23.18)\end{array}$ & $\begin{array}{c}-0.048^{* * *} \\
(-15.73)\end{array}$ & $\begin{array}{c}-0.070^{* * *} \\
(-23.29)\end{array}$ & $\begin{array}{c}-0.047^{* * *} \\
(-16.15)\end{array}$ & $\begin{array}{c}-0.072^{* * *} \\
(-23.90)\end{array}$ & $\begin{array}{c}-0.049^{* * *} \\
(-16.72)\end{array}$ \\
\hline Median Age & $\begin{array}{c}0.121^{* * *} \\
(3.65)\end{array}$ & $\begin{array}{c}0.176^{* * *} \\
(5.93)\end{array}$ & $\begin{array}{l}0.065 \\
(1.95)\end{array}$ & $\begin{array}{c}0.152^{* * *} \\
\quad(5.12)\end{array}$ & $\begin{array}{c}0.073^{*} \\
(2.16)\end{array}$ & $\begin{array}{c}0.157^{* * *} \\
\quad(5.28)\end{array}$ \\
\hline Square of Median Age & $\begin{array}{l}-0.001 \\
(-1.53)\end{array}$ & $\begin{array}{c}-0.001^{* *} \\
(-2.99)\end{array}$ & $\begin{array}{l}0.000 \\
(0.20)\end{array}$ & $\begin{array}{c}-0.001^{*} \\
(-2.10)\end{array}$ & $\begin{array}{l}-0.000 \\
(-0.02)\end{array}$ & $\begin{array}{c}-0.001^{*} \\
(-2.25)\end{array}$ \\
\hline Urban & $\begin{array}{c}-0.938^{* * *} \\
(-8.20)\end{array}$ & $\begin{array}{c}-0.603^{* * *} \\
(-5.63)\end{array}$ & $\begin{array}{c}-1.020^{* * *} \\
(-9.02)\end{array}$ & $\begin{array}{c}-0.639^{* * *} \\
(-6.03)\end{array}$ & $\begin{array}{c}-1.015^{* * *} \\
(-8.98)\end{array}$ & $\begin{array}{c}-0.642^{* * *} \\
(-6.05)\end{array}$ \\
\hline 1997. Year & $\begin{array}{c}-0.452^{* * *} \\
(-15.85)\end{array}$ & $\begin{array}{c}-0.497^{* * *} \\
(-21.05)\end{array}$ & $\begin{array}{c}-0.518^{* * *} \\
(-17.39)\end{array}$ & $\begin{array}{c}-0.544^{* * *} \\
(-20.81)\end{array}$ & $\begin{array}{c}-0.529^{* * *} \\
(-17.78)\end{array}$ & $\begin{array}{c}-0.558^{* * *} \\
(-21.30)\end{array}$ \\
\hline 2005. Year & $\begin{array}{c}-0.848^{* * *} \\
(-23.13)\end{array}$ & $\begin{array}{c}-0.919^{* * *} \\
(-28.94)\end{array}$ & $\begin{array}{c}-0.931^{* * *} \\
(-24.68)\end{array}$ & $\begin{array}{c}-0.977^{* * *} \\
(-28.28)\end{array}$ & $\begin{array}{c}-0.949^{* * *} \\
(-25.15)\end{array}$ & $\begin{array}{c}-1.000^{* * *} \\
(-28.85)\end{array}$ \\
\hline Residence Time & & & $\begin{array}{l}-0.000 \\
(-1.40)\end{array}$ & $\begin{array}{l}-0.000 \\
(-0.42)\end{array}$ & $\begin{array}{l}-0.000 \\
(-1.37)\end{array}$ & $\begin{array}{l}-0.000 \\
(-0.48)\end{array}$ \\
\hline Working Women & & & $\begin{array}{c}0.064^{* * *} \\
(10.23)\end{array}$ & $\begin{array}{c}0.042^{* * *} \\
(5.24)\end{array}$ & $\begin{array}{c}0.064^{* * *} \\
(10.25)\end{array}$ & $\begin{array}{c}0.042^{* * *} \\
(5.23)\end{array}$ \\
\hline Population Density & & & & & $\begin{array}{c}-0.000^{* * *} \\
(-4.06)\end{array}$ & $\begin{array}{c}-0.000^{* * *} \\
(-3.73)\end{array}$ \\
\hline Constant & $\begin{array}{c}7.760^{* * *} \\
(10.48)\end{array}$ & $\begin{array}{l}-0.633 \\
(-0.89)\end{array}$ & $\begin{array}{c}7.537^{* * *} \\
(10.02)\end{array}$ & $\begin{array}{l}-0.691 \\
(-0.95)\end{array}$ & $\begin{array}{c}7.679^{* * *} \\
(10.20)\end{array}$ & $\begin{array}{l}-0.543 \\
(-0.75)\end{array}$ \\
\hline State Dummy Variables Used? & No & Yes & No & Yes & No & Yes \\
\hline Observations & 9324 & 9324 & 9320 & 9320 & 9320 & 9320 \\
\hline
\end{tabular}


Table 10: Preferred Specification: Fixed-Effect Model

\begin{tabular}{|c|c|c|c|c|}
\hline $\begin{array}{l}\text { Dependent Variable: } \\
\text { Social Capital }\end{array}$ & (1) & $(2)$ & $(3)$ & (4) \\
\hline Ethnic Fractionalization & $\begin{array}{c}-1.575^{* * *} \\
(-5.69)\end{array}$ & $\begin{array}{c}-0.891^{* *} \\
(-2.81)\end{array}$ & $\begin{array}{c}-4.623^{* * *} \\
(-6.15)\end{array}$ & $\begin{array}{c}-4.076^{* * *} \\
(-5.32)\end{array}$ \\
\hline Income Per Capita & $\begin{array}{l}0.000 \\
(0.30)\end{array}$ & $\begin{array}{l}0.000 \\
(0.27)\end{array}$ & $\begin{array}{l}0.000 \\
(0.29)\end{array}$ & $\begin{array}{l}0.000 \\
(0.25)\end{array}$ \\
\hline Education Level & $\begin{array}{l}0.005 \\
(1.25)\end{array}$ & $\begin{array}{c}0.011^{* *} \\
(2.62)\end{array}$ & $\begin{array}{l}0.006 \\
(1.51)\end{array}$ & $\begin{array}{c}0.012^{* *} \\
(2.88)\end{array}$ \\
\hline Family Households & $\begin{array}{l}0.000 \\
(0.12)\end{array}$ & $\begin{array}{l}-0.005 \\
(-1.36)\end{array}$ & $\begin{array}{l}0.000 \\
(0.11)\end{array}$ & $\begin{array}{l}-0.006 \\
(-1.38)\end{array}$ \\
\hline Median Age & $\begin{array}{c}-0.330^{* * *} \\
(-13.57)\end{array}$ & $\begin{array}{c}-0.301^{* * *} \\
(-11.20)\end{array}$ & $\begin{array}{c}-0.327^{* * *} \\
(-13.48)\end{array}$ & $\begin{array}{c}-0.299^{* * *} \\
(-11.16)\end{array}$ \\
\hline Square of Median Age & $\begin{array}{c}0.004^{* * *} \\
(14.70)\end{array}$ & $\begin{array}{c}0.004^{* * *} \\
(13.37)\end{array}$ & $\begin{array}{c}0.004^{* * *} \\
(14.69)\end{array}$ & $\begin{array}{c}0.004^{* * *} \\
(13.40)\end{array}$ \\
\hline Urban & $\begin{array}{c}-1.015^{* * *} \\
(-7.55)\end{array}$ & $\begin{array}{c}-1.003^{* * *} \\
(-7.47)\end{array}$ & $\begin{array}{c}-1.006^{* * *} \\
(-7.49)\end{array}$ & $\begin{array}{c}-0.993^{* * *} \\
(-7.41)\end{array}$ \\
\hline Population Density & $\begin{array}{l}-0.000 \\
(-0.86)\end{array}$ & $\begin{array}{l}-0.000 \\
(-0.63)\end{array}$ & $\begin{array}{l}-0.000 \\
(-0.92)\end{array}$ & $\begin{array}{l}-0.000 \\
(-0.69)\end{array}$ \\
\hline Residence Time & $\begin{array}{l}-0.000 \\
(-1.00)\end{array}$ & $\begin{array}{l}-0.000 \\
(-0.96)\end{array}$ & $\begin{array}{l}-0.000 \\
(-1.02)\end{array}$ & $\begin{array}{l}-0.000 \\
(-0.98)\end{array}$ \\
\hline Working Women & $\begin{array}{c}0.028^{* * *} \\
(5.19)\end{array}$ & $\begin{array}{l}0.029^{* * *} \\
(5.18)\end{array}$ & $\begin{array}{c}0.028^{* * *} \\
(5.30)\end{array}$ & $\begin{array}{c}0.029^{* * *} \\
(5.25)\end{array}$ \\
\hline 1997.Year & & $\begin{array}{c}-0.077^{*} \\
(-2.43)\end{array}$ & & $\begin{array}{c}-0.075^{*} \\
(-2.37)\end{array}$ \\
\hline 2005.Year & & $\begin{array}{c}-0.226^{* * *} \\
(-4.47)\end{array}$ & & $\begin{array}{c}-0.227^{* * *} \\
(-4.49)\end{array}$ \\
\hline Racial Dominance & & & $\begin{array}{c}-4.347^{* * *} \\
(-4.36)\end{array}$ & $\begin{array}{c}-4.545^{* * *} \\
(-4.56)\end{array}$ \\
\hline Constant & $\begin{array}{c}6.811^{* * *} \\
(10.55)\end{array}$ & $\begin{array}{c}6.176^{* * *} \\
(8.94)\end{array}$ & $\begin{array}{c}11.08^{* * *} \\
(9.45)\end{array}$ & $\begin{array}{c}10.65^{* * *} \\
(8.88)\end{array}$ \\
\hline Observations & 9324 & 9324 & 9324 & 9324 \\
\hline
\end{tabular}


Table 11: Correlation Matrix (Race Variables vs. Largest Racial Percentage)

\begin{tabular}{lcc}
\hline \hline & Racial Dominance & Ethnic Fractionalization \\
\hline Ethnic Fractionalization & -0.979 & 1.000 \\
White Proportion & 0.953 & -0.931 \\
Black Proportion & -0.747 & 0.706 \\
Latino Proportion & -0.492 & 0.508 \\
Asian Proportion & -0.238 & 0.293 \\
\hline Observations & 9324 & 9324 \\
\hline \hline
\end{tabular}

of proxy variables and their correlation with racial dominance. We choose the Black proportion as our proxy variable because it is the best choice among our available options. First, the Asian proportion variable is rejected because while it is not as correlated with racial dominance, it is also not correlated strongly with ethnic fractionalization. The Latino variable is also not preferable because it is correlated significantly with ethnic fractionalization, but not as highly correlated with racial dominance as ethnic fractionalization. Further, individuals who identify as Latino can also be Black or White which makes Latino as a group more difficult to distinguish from Whites and Blacks. The proportion Whites is also not a good option because it is as correlated with racial dominance as ethnic fractionalization and hence will suffer similar problems discussed above.

In contrast, the Black proportion is highly correlated with ethnic fractionalization (more so than Latino and Asian) (see also figure 1), but not as correlated with racial dominance (less so than white proportion) making it a good proxy. This lower correlation with racial dominance potentially should mitigate the issues of multicollinearity. However, it is possible to argue that the Black proportion variable may still suffer from imprecise estimates given its correlation with racial dominance. We highlight in the next section evidence that this is really not the case in our data.

We re-estimate our empirical model using Black proportion as a proxy for ethnic fractionalization and make use of our preferred empirical specification, the fixed effect model. Table (12) provides results using the Black proportion of the population as a proxy for ethnic fractionalization. ${ }^{14}$ The

\footnotetext{
${ }^{14}$ See the appendix for a summary of the full regression estimates using the proportion
} 


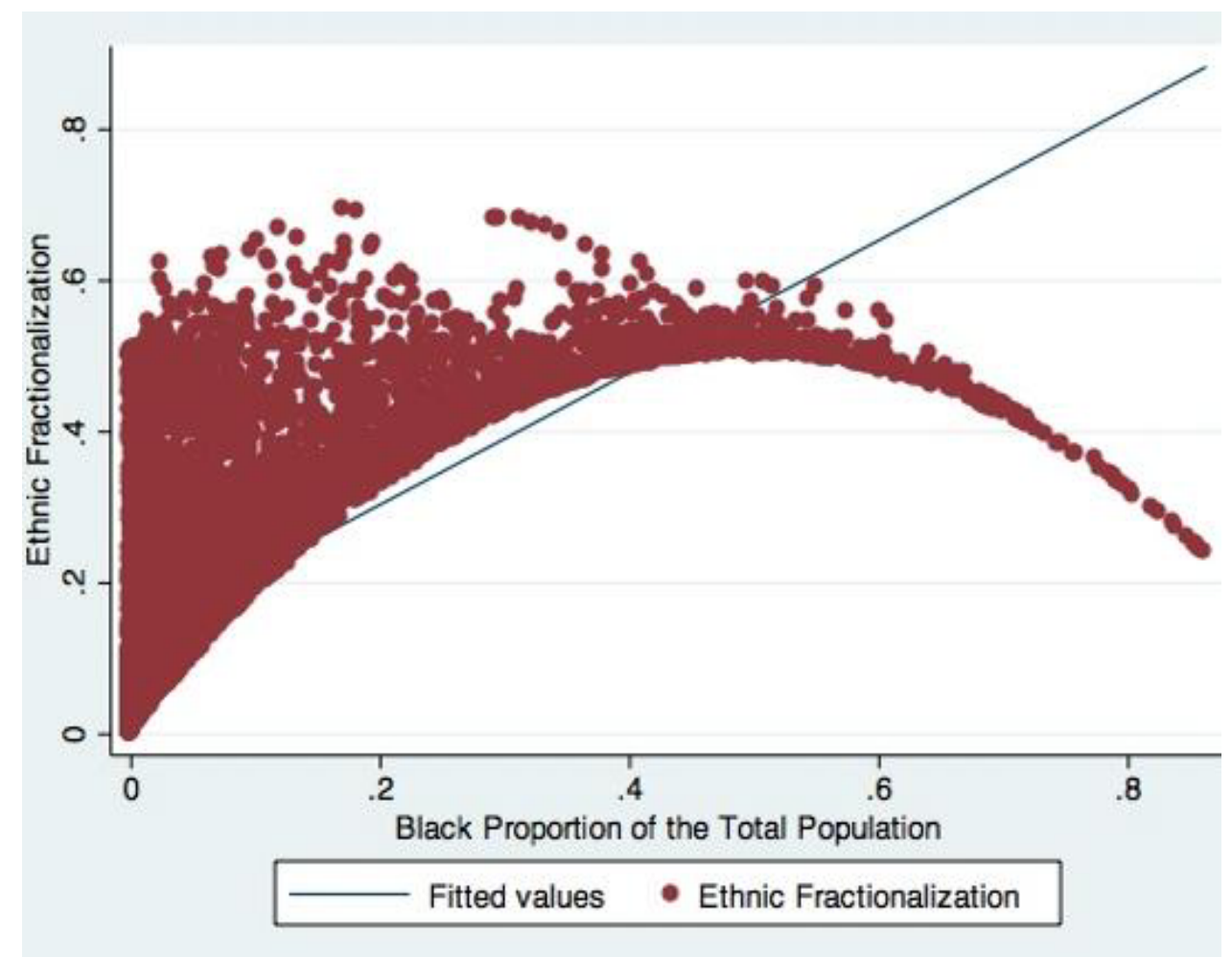

Figure 1: Black Fraction of the Population vs. Ethnic Fractionalization 
estimated coefficients in columns (1) and (2) allows us to test how well the Black proportion of the population works as a proxy for ethnic fractionalization. These results suggest that using the Black proportion increases the magnitude of our estimated effect, but since effects are negative, estimates are downwardly biased. Just as above, we can reject the contact theory based on the results summarized in these columns. The estimated Black proportion in columns (3) and (4) of Table (12) are not statistically different from the estimates in columns (1) and (2). This suggests that the inclusion of largest dominant group in columns (3) and (4) is not significantly biasing the estimate of the effect of Black proportion (our proxy for ethnic fractionalization). Hence, the potential problem of multicollinearity leading to imprecise estimates because of the correlation between the Black proportion variable and racial dominance is not relevant in our case. In contrast, recall in Table (10) columns (3) and (4) the estimated effects of ethnic fractionalization changed significantly with the inclusion of the racial dominance variable signaling multicollinearity problems.

Notice also from columns (3) and (4) that when we use the Black proportion as a proxy for ethnic fractionalization, there is greater support for the conflict theory as the estimated coefficient for the Black proportion variable is negative while the estimated coefficient for the racial dominance variable is either 0 or positive. In our preferred specification, column (4), the racial dominance variable is nonsignificant suggesting that there is no support for the hunker-down theory and the noted significant negative effects in earlier tables are misleading and the result of collinearity between the ethnic fractionalization and the racial dominance variables.

\section{Conclusion and Inferences}

In this paper we first test for time differences in the impact of ethnic fractionalization on social capital accumulation. Subsequently, we check to see if any of Putman's models on social capital evolution over time is consistent with our data. Our results show that though ethnic fractionalization has increased over time in the U.S., there is no significant change in the impact of ethnic fractionalization on social capital. This result suggests that the relationship between social capital and ethnic fractionalization is stable over the evaluation period (1990-2005).

What do our results say about Putnam's theories? We find evidence against Putnam's contact theory due to the negative relationship between

of Blacks as a proxy for ethnic fractionalization. 
Table 12: Fixed Effect Results (Using Black Proportion as a Proxy)

\begin{tabular}{lcccc}
\hline \hline Dependent Variable: & $(1)$ & $(2)$ & $(3)$ & $(4)$ \\
Social Capital & \multicolumn{2}{c}{ Testing Contact Hypothesis } & Conflict vs. Hunker-Down Hypothesis \\
\hline Black Proportion & $-2.525^{* * *}$ & $-2.232^{* * *}$ & $-1.989^{* *}$ & $-2.484^{* * *}$ \\
& $(-4.35)$ & $(-3.85)$ & $(-3.15)$ & $(-3.92)$ \\
Racial Dominance & & & $0.857^{*}$ & -0.438 \\
& & & $(2.14)$ & $(-0.97)$ \\
Year Dummies & No & Yes & No & Yes \\
\hline Observations & 9324 & 9324 & 9324 & 9324 \\
\hline \hline & & & & \\
${ }^{*}$ Note $t$ statistics in parentheses & & & \\
${ }^{*}$ In the regressions summarized in this table we also include all the controls used in the results in Table 8.
\end{tabular}

diversity and social capital. Our results are consistent with the conflict theory that suggests that increase in diversity leads to decline in social capital. However, the magnitude of the estimated impact of ethnic fractionalization is small.

Specifically, our preferred model [Table (10) columns (2)], suggests a coefficient of (0.891) implying that $100 \%$ change in ethnic fractionalization would lead to a 0.891 percent change in social capital. A reasonable change in ethnic fractionalization is about $4 \%$ ( which is the change in the mean between 1990 and 2005) and this would lead to a change of approximately 0.04 in social capital. ${ }^{15}$

Our results also show the lack of a significant relationship between racial dominance and social capital. This suggests thats Putnam's hunker-down theory is not consistent with our data. However, the data does appear to empirically support the conflict theory.

It is important to mention that this analysis has two limitations. First, we consider social capital using pre-existing measures. Though consistent with the way social capital was formed in the past, these measures may not be as relevant for social capital formation for younger generations. Those born in the 70s and the Millennials have grown-up with a huge internet presence, advanced communication technologies and social media. They are networking and forming groups in ways that are quite different from older generations and it is reasonable to assume these groups will also create social capital. Hence, this measure of social capital would be downward biased for the younger cohorts. Second, while the fixed effects model allows us to

\footnotetext{
${ }^{15} \mathrm{~A}$ change of 0.04 is a small change in our social capital measure.
} 
identify effects of fractionalization on social capital using variation within a county over time, eliminating most sources of selectivity and bias, our results are still threatened with possible unobservables that are correlated with social capital and ethnic fractionalization. Though such a variable is unlikely, we cannot rule it out.

In summary, our results suggest that as communities evolve in the U.S, with increase in ethnic fractionalization, individuals trust new entrants less which leads to less social capital. However, this cost of increased immigration and migration, which are the primary sources of increase in ethnic diversity in communities, could be far out weighed by the documented benefits of immigrant increases within communities in the U.S. Hence, though diversity may lead to a decrease in social capital as captured by our measures, our results do not provide evidence of the impact of diversity on other welfare outcomes or alternative measures of social capital. Given the nature of our finding, further studies are needed to determine whether the positive effects of diversity and immigration outweighs the negative effects on social capital. In addition, there is a need for a more comprehensive measure of social capital that includes in its calculation, the types of groups and networks that younger cohorts belong to. 


\section{References}

[1] Alesina, Alberto and Eliana LaFerrara. (2004). Ethinic Diversity and Economic Performance. NBER Working Paper 10313, National Bureau of Economic Reserach.

[2] Arrow, Kenneth J. (2000) Observations on Social Capital. Social Capital: A Multifaceted Perspective, Edited by Partha Dasgupta and Ismail Serageldin. The International Bank of Reconstruction.

[3] Blau, Peter M. (1977) Inequality and Heterogeneity: A Primitive Theory of Social Structure, New York: Free Press.

[4] Card, David. (2005) Is the New Immigration Really So Bad? Economic Journal, 115, F300-F323.

[5] Chhibber, Ajay, et al. (1997) The State in a Changing World. World Development Report, 1997. Oxford University Press, Inc., 2001 Evans Rd., Cary, NC 27513, 1997.

[6] Colman J.S. (1988). The Creation and Destruction of Social Capital: Inplications for the Law. Notre Dame Journal of Law, Ethics, and Public Policy 3:375-404.

[7] Colman J.S. (1990) Foundations of Social Theory, Cambridge: Belknap Press of Harvard University Press (1990)

[8] Diette, Timothy M. and Ruth Uwaifo Oyelere, (2014). Gender and Race Heterogeneity: The Impact of Students with Limited English on Native Students' Performance, American Economic Review, American Economic Association, vol. 104(5), pages 412-17, May.

[9] DeFilippis, J. (2001) The Myth of Social Capital in Community Development Housing Policy Debate 12, 781-806.

[10] Durlauf, S.N. (2002). Symposium on social capital: introduction, Economic Journal, 112, F417-18.

[11] Helliwell, John F., and Robert D. Putnam. (2004) The social context of well-being. Philosophical transactions-royal society of London series B biological sciences: 1435-1446.

[12] McPherson, J., Popielarz, P. A., and Drobnic, S. (1992). Social Networks and Organizational Dynamics. American Sociological Review, 57(2), 153-170. 
[13] Narayan, Deepa, and Lant Pritchett. (1997). Cents and Sociability: Household Income and Social Capital in Rural Tanzania.

[14] North, Douglas C. and Robert P. Thomas. (1973). The Rise of the Western World: A New Economic History. Cambridge: Cambridge University Press.

[15] Olson, Mancur. (1971). The Logic of Collective Action: Public Goods and the Theory of Groups. (Revised edition ed.). Harvard University Press. 1965.

[16] Ottaviano, Gianmarco IP, and Giovanni Peri. (2012) Rethinking the effect of immigration on wages. Journal of the European Economic Association 10.1 (2012): 152-197.

[17] Portes, Alejandro.(1998) Social Capital: Its Origins and Applications in Modern Sociology, Annual Review of Sociolgy, 24, 1-24

[18] Putnam, Robert (1993) Making Democracy Work: Civic Traditions in Modern Italy Princeton University Press

[19] Putnam, Robert (1999) Bowling Alone: America's Declining Social Capital. Journal of Democracy 6 (1): 65-78.

[20] Putnam, Robert (2000) Bowling Alone: The Colapse and Revival of American Community. New York,Simon and Schuster.

[21] Putnam, Robert E. Pluribus Unum: (2007) Diversity and Community in the Twenty-first Century The 2006 Johan Skytte Prize Lecture. The Scandiavian Political Studies Vol. 30, No. 2: 137-174.

[22] Rupasingha, Anil, Stephan J. Goetz, and David Freshwater. (2006) The production of social capital in US counties. The Journal of Socioeconomics 35.1 : 83-101.

[23] Sowlow, Robert. (2000) Notes on Social capital and Economic Perfomance. Social Capital: A Multifaceted Perspective, Edited by Partha Dasgupta and Ismail Serageldin. The International Bank of Reconstruction

[24] U.S. Census Bureau. (2010). USA Counties- Demographic data. [Table]. Retrieved from http://www.censtats.census.gov/usa/usa.shtml 


\section{Appendix}

\section{Appendix A: Description of Independent Variables used in Analysis}

The ethnic fractionalization variable measures the level of diversity within a county.

Ethnic Fractionalization $=1-\sum_{i}{\text { Race } \text { Variable }_{i} \mid} i=$ Black, White, Asian, Latino

where the race variable is the proportion of a population that identifies with race (i), which can be Black, White, Asian or Latino. This is the same method used in Rupasingha et al (2006).

The racial dominance variable idenifies the proportion of the majority race in a given community. Larger values imply a more dominant race within a county. Racial dominance is defined as follows:

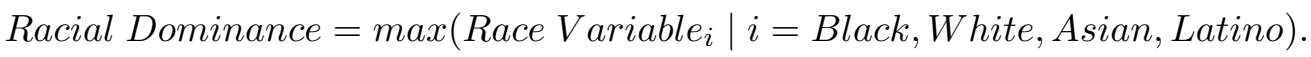

Racial dominance is defined across four racial groups, Black, White, Latino and Asian.

The race variables is calculated by dividing the population of race $i$ by the total number of blacks, whites, latinos and asians in a particular county.

Race $_{\text {Variable }}=\frac{\text { Race Population }}{i}$

Ethnic fractionalization, racial dominance, and racial proportion data were all collected from 1990, 2000, and 2005 for the 1990, 1997, and 2005 panels, respectively. Income per capita was collected from 1989, 1999, and an average from 2005-2009 for the 1990, 1997, and 2005 panels, respectively. Education level was collected from 1990, 2000, and an average from 20052009 for the 1990, 1997, and 2005 panels, respectively.

The proportion of family households was derived from components gathered from 1990, 2000, and an average from 2005-2009 for the 1990, 1997, and 2005 panels, respectively. The calculation for this variable is shown below:

$$
\text { Proporton of Family Households }=\frac{\text { Family Households }}{\text { Total Households }}
$$

This represents the proportion of households that are family units. 
Median age data was taken from the U.S. census of 1990, 2000, and 2010 for the 1990, 1997, and 2005 panels, respectively. We are forced to use median age data from 2010 rather than using 2000 census data for both 2000 and 2005 panels.

The determination of whether a county is urban was based on population data collected from the 1990, 1997, and 2005 time periods for their respective panels.

The calculation for population density is as follows:

$$
\text { Population Density }=\frac{\text { Total Population }}{\text { Area }}
$$

Total population data was collected from 1990, 1997, and 2005 time periods for the respective panels. Land area was collected from 1990, 2000, and 2010 for the 1990, 1997, and 2005 panels, respectively.

Residence time was approximated using an engineering equation to calculate the time a particle spends in a specified vessel. An assumption behind this equation is that a given town has the capacity for a set amount of people, which is more accurate over a short period of time. The equation is as follows:

$$
\text { Residence Time }=10 * \frac{\text { Total Population }}{\Delta \text { Population } 10 \text { years }}
$$

The 10 year change in population was collected from change from 19801990, 1990-2000, and 2000-2010 for the the 1990, 1997, and 2005 panels, respectively.

The percentage of women working in the overall population was calculated with the following equation:

$$
\text { Percent of Women Working }=100 * \frac{\text { Working Women }}{\text { Total Population }}
$$

Data on the total number of working women in a county was collected from components gathered from 1990, 2000, and an average from 2005-2009 for the 1990, 1997, and 2005 panels, respectively. 
Table 13: Full Regression Estimates Fixed Effect (Using Black Proportion as a Proxy)

\begin{tabular}{|c|c|c|c|c|}
\hline & $\begin{array}{c}(1) \\
\text { skipcm }\end{array}$ & $\begin{array}{c}(2) \\
\text { skipcm }\end{array}$ & $\begin{array}{c}(3) \\
\text { skipcm }\end{array}$ & $\begin{array}{c}(4) \\
\text { skipcm }\end{array}$ \\
\hline Black Proportion & $\begin{array}{c}-2.525^{* * *} \\
(-4.35)\end{array}$ & $\begin{array}{c}2.232^{* * *} \\
(-3.85)\end{array}$ & $\begin{array}{c}-1.989^{* *} \\
(-3.15)\end{array}$ & $\begin{array}{c}-2.484^{* * *} \\
(-3.92)\end{array}$ \\
\hline Racial Dominance & & & $\begin{array}{l}0.857^{*} \\
(2.14)\end{array}$ & $\begin{array}{l}-0.438 \\
(-0.97)\end{array}$ \\
\hline Income Per Capita & $\begin{array}{l}0.000 \\
(0.29)\end{array}$ & $\begin{array}{l}0.000 \\
(0.24)\end{array}$ & $\begin{array}{l}0.000 \\
(0.29)\end{array}$ & $\begin{array}{l}0.000 \\
(0.24)\end{array}$ \\
\hline Education Level & $\begin{array}{c}-0.002 \\
(-0.50)\end{array}$ & $\begin{array}{c}0.009^{*} \\
(2.34)\end{array}$ & $\begin{array}{l}0.001 \\
(0.17)\end{array}$ & $\begin{array}{c}0.009^{*} \\
(2.25)\end{array}$ \\
\hline Family Households & $\begin{array}{l}0.001 \\
(0.38)\end{array}$ & $\begin{array}{l}-0.007 \\
(-1.80)\end{array}$ & $\begin{array}{l}0.001 \\
(0.22)\end{array}$ & $\begin{array}{l}-0.008 \\
(-1.89)\end{array}$ \\
\hline Median Age & $\begin{array}{c}-0.343^{* * *} \\
(-14.21)\end{array}$ & $\begin{array}{c}-0.293^{* * *} \\
(-10.93)\end{array}$ & $\begin{array}{c}-0.337^{* * *} \\
(-13.91)\end{array}$ & $\begin{array}{c}-0.290^{* * *} \\
(-10.78)\end{array}$ \\
\hline Square of Median Age & $\begin{array}{c}0.004^{* * *} \\
(15.30)\end{array}$ & $\begin{array}{c}0.004^{* * *} \\
(13.14)\end{array}$ & $\begin{array}{c}0.004^{* * *} \\
(14.98)\end{array}$ & $\begin{array}{c}0.004^{* * *} \\
(13.09)\end{array}$ \\
\hline Urban & $\begin{array}{c}-1.035^{* * *} \\
(-7.69)\end{array}$ & $\begin{array}{c}-1.012^{* * *} \\
(-7.54)\end{array}$ & $\begin{array}{c}-1.032^{* * *} \\
(-7.66)\end{array}$ & $\begin{array}{c}-1.012^{* * *} \\
(-7.54)\end{array}$ \\
\hline Population Density & $\begin{array}{l}-0.000 \\
(-1.06)\end{array}$ & $\begin{array}{l}-0.000 \\
(-0.70)\end{array}$ & $\begin{array}{l}-0.000 \\
(-0.98)\end{array}$ & $\begin{array}{l}-0.000 \\
(-0.71)\end{array}$ \\
\hline Residence Time & $\begin{array}{c}-0.000 \\
(-0.95)\end{array}$ & $\begin{array}{l}-0.000 \\
(-0.93)\end{array}$ & $\begin{array}{c}-0.000 \\
(-0.96)\end{array}$ & $\begin{array}{l}-0.000 \\
(-0.92)\end{array}$ \\
\hline Working Women & $\begin{array}{c}0.029^{* * *} \\
(5.40)\end{array}$ & $\begin{array}{c}0.030^{* * *} \\
(5.55)\end{array}$ & $\begin{array}{c}0.028^{* * *} \\
(5.28)\end{array}$ & $\begin{array}{c}0.031^{* * *} \\
(5.63)\end{array}$ \\
\hline 1997.Year & & $\begin{array}{c}-0.110^{* * *} \\
(-3.88)\end{array}$ & & $\begin{array}{c}-0.123^{* * *} \\
(-3.93)\end{array}$ \\
\hline 2005.Year & & $\begin{array}{c}-0.283^{* * *} \\
(-6.40)\end{array}$ & & $\begin{array}{c}-0.305^{* * *} \\
(-6.12)\end{array}$ \\
\hline Constant & $\begin{array}{c}7.028^{* * *} 35 \\
(10.84)\end{array}$ & $\begin{array}{c}6.118^{* * *} \\
(8.94)\end{array}$ & $\begin{array}{c}6.147^{* * *} \\
(8.01)\end{array}$ & $\begin{array}{c}6.466^{* * *} \\
(8.38)\end{array}$ \\
\hline Observations & 9320 & 9320 & 9320 & 9320 \\
\hline
\end{tabular}

